\title{
The Dichotomy of Capacity Building and Unemployment in Ethiopia
}

DIBIE, Robert | DIBIE, Josephine

\section{Abstract}

This paper examines the problems associated with youth capacity building and unemployment in Ethiopia. It argues that capacity building is a continuous process of development that could be accomplished through participation of the citizens in their own development. The dynamics of development at both national and grassroots levels in Ethiopia must involve the exposure of government change agents to participatory learning and action methodologies. The paper uses data derived from primary and secondary sources to analyze the problems associated with youth capacity building and unemployment in Ethiopia. The conceptual framework is based on the social constructionist, the build block model of development, monetarist and the Keynesian theories. The findings show that technical capacity building in Ethiopia will serve as a lever for economic and social development. There is, however, a negative correlation between the nation's educational system and the kind of technical skills needed to achieve its sustainable development goals. In addition, the Ethiopian Government policies have not been able to effectively galvanize the private sector and NGOs to create more jobs for youths. Further, current government policy tends to focus on the supply side. Less emphasis has been placed on the demand side and comparable strategies to address the youth unemployment problems. The paper recommends that the in the new global economy, young people need to acquire more than just basic education, and curricula. They should be influenced by the current trends in of globalization, regional integration and technological transformation. The established public labour-intensive infrastructure projects in urban areas, like cobblestone, housing, Micro and Small Enterprises and others, need to be strengthened and supported by government, private sectors and NGOs, both technically and financially. Thus, government, private sector and NGOs should collaborate to establish a mechanism for a better and efficient approach to providing youth employment all over Ethiopia and in Addis Ababa in particular. It further suggests that appropriate monetary and fiscal policies are necessary for Ethiopia to effectively address its urban youth capacity building problems.

Keywords: Capacity Building, Sustainable Development, Technical Skill, Basic Education, Technological Transformation. 


\section{Introduction}

One of the greatest challenges facing Ethiopia today is restoring its economic strength and sustainability goals. Fortunately, this challenge comes amidst favourable environmental renaissance that could reverse more than a decade of famine and severe poverty. Indeed, the current positive environmental conditions have become a catalyst for economic growth, bringing affordable energy, jobs, revenues and an accompanying resurgence of manufacturing and agricultural products (United Nations Human Development Index, 2012:137). Despite these resurgence in agriculture after several years of drought and famine, the challenges to sustainability especially youth capacity building in Ethiopia has become marred with problems. The ability to deal with economic and social changes, engage in responsible and ethical business practices, provide high quality product and services, as well as develop methods and measure to determine if the government is meeting its citizens needs have not been very effective (Dibie, 2010:4). The extent to which the government has been able to address the sustainability challenges of human resources capacity as well as a holistic approach to capitalizing on the strengths of a diverse workforce has not been encouraging. Despite the political and economic stability in the country for almost two decades the nation has not been able to attract and retain a committed productive workforce in turbulent economic conditions that offer opportunity for financial success but severely ignored youth capacity building (Ethiopian Economic Association/EEA/, 2005-2006; World Bank, 2011:27).

The development of entrepreneurship in Ethiopia has been faced with a lot of challenges such as technical skill, inadequate funds, incentives, well equipped vocational and technical training institutions, progressive educational system, and poor managerial skills. Many of unemployed youths in the country today are creative but they are incapacitated because they do not have enough funds to start a business that could make them self-reliant (Dibie, 2014:429).

According to Tegegn Gebeyaw and Tesfaye Chofana (2012) millions of Ethiopians especially the youth and women are unemployed, underemployed or are in the swelling ranks of the working poor. The 2010 urban employment survey by the Ethiopian Central Statistical Agency (2012:16) reported that 4,790,958 million out of the 5,907,470 million labour force were employed with the remaining 1,116,512 million people unemployed. This means that the urban population unemployment rate is about 18.9 percent. The 
corresponding female unemployment rate is reported to be 27.4 percent while the male unemployment rate is 11 percent (Ethiopian Central Statistics Agency, 2011:9).

According to the United Nations Human Development Index (2012:13) youth between 16 and 25 represent more than 60 percent of Africa's total population and account for 45 per cent of the total labour force. In Ethiopia it is estimated that the youth represent 25 percent of the nation's working-age population and this figure may increase in the next two decades. In addition to youth population growth, increased poverty, environmental degradation and unemployment are problems facing most countries in sub-Saharan Africa including Ethiopia. It is expected that this increase in the number of youth will not decline in the next four decades or more. To compound the capacity building problems in Ethiopia, the high cost of seeking educational and vocational skills is increasingly causing millions of unemployed and underemployed youth in the country to turn into criminals (Eita et al., 2010:11). The underlying problems have resulted in a large number of youth under 15 years old to seek employment every year. Several youth of this age group have also left the country in search of domestic employment in Arab and western industrialized countries (Nebil et al., 2010: Abebe \& Alemu 2013:9). Furthermore, the lack of employment opportunities have given rise to other economic and social problems in the society, such as increased crimes, suicides, poverty, alcoholism and prostitution (Rafik et al., 2010; Eita et al., 2010:13). There has also been a causal relationship between high unemployment rates and the spread of HIV/AIDS in Ethiopia (Haile, 2003:4). In addition, the lack of employment opportunities in the country has spilled over to health issues, low household income, stagnated government revenue and, hence, deplorable GDP and the inability to effectively implement sustainable development strategic plan goals. Growing impact of unemployment exacerbated other economic problems such as home foreclosures and the credit card debt, caused number of bankruptcies among people who worked all their lives (Peters, 2013:64)

The Labour and Social Affairs Bureau of Addis Ababa (2013) reported that the current adult unemployment rate is about twenty percent, while youth unemployment ranges from 30 to 35 percent. The Labour and Social Bureau also reported that Ethiopia's rapid population growth combined with rural-urban migration resulted in a massive increase in the unemployment rate in Addis Ababa, the nation's capital city. Basically, unemployed urban youth groups include those people who are not willing to take up any job 
opportunity but would prefer to wait until they are able to find appropriate jobs with an acceptable salary consistent with their qualification and experience (Abebe \& Alemu, 2013:12).

The Government of Ethiopia introduced measures in the past to address the youth unemployment predicament. These reform policies include labour market laws, and decentralization of public spending. They also created enabling entrepreneurship environments, to improve the quality of education, stimulate innovation and develop skills through Technical Vocational Education Training (TVET), private sectors involvement, as well as business development services. Despite, these policies by both the national and Addis Ababa city governments, the youth unemployment problems have not been effectively resolved. This policy dilemma has resulted in citizens' further request for different approach to address the unemployment issue (Abebe 2011; Nebil et al., 2010:21).

According to Kraft and Furlong (2013:171) the five major economic goals that government should use to promote economic growth include low levels of unemployment, low levels of inflation, a positive balance of trade, and the management of deficits and debt. There is very scanty evidence to show that the Government of Ethiopia has effectively utilized these economic growth policy instruments.

This paper examines the problem associated with youth capacity building and unemployment in Ethiopia. It argues that the ideal platform for capacity building is a partnership planning approach. Through partnership citizens could buy into the program and benefit from the various transformation skills. Appropriate capacity building programs could also attract or enhance motivates for citizens to share in, belong to, influence and direct the development process, and establish dignity and self-esteem. There is higher percentage of female unemployment than their male counterparts in Ethiopia. The trend of higher percentage of female unemployment in the country may result in girl's vulnerability to other social problems.

The conceptual framework is based on three theories. On one hand, the social constructionist and monetarist theories that promote engaging in partnership action and mutual society learning changes as well the used of fiscal and monetary policies to directly determine changes in prices, real GDP, and employment (Mandel, 2012). On the other hand, the Keynesian theory argues that the economy is unstable at less than full employment, price and wages are inflexible, and velocity of money is stable. As a result, 
excess demand causes inflation, inadequate demand causes unemployment, and monetary policy can change interest rates and level of GDP, as a result fiscal policies may be necessary (Mankiw, 2012:206). This paper suggests that appropriate monetary and fiscal policies are necessary for Ethiopia to effectively address its urban youth unemployment problems. It uses data derived from primary and secondary sources to analyze the problem associated with youth capacity building and unemployment in Ethiopia.

The data were analyzed to find out the trends and employment policy efforts. Respondents of the survey include employed and unemployed youth, members of local and national governments, the private sector, and nongovernmental organizations (NGOs). The findings reveal that there is a negative correlation between the education system and the technical skills the nation need most to develop. It recommends that the government, private sector and NGOs should collaborate to establish a mechanism for a better and efficient approach to providing youth employment all over Ethiopia.

\section{Conceptual Framework of Capacity Building and Economic Growth}

It is no secret that domestic growth in Ethiopia is important because it provides a foundation for the future of its society. Economic growth can contribute to advancements in all fields, creating beneficial outcomes and solutions to many economic problems. Economic growth is important because it keeps all nations moving in a positive, productive direction. The more economic growth in Ethiopia, the better for the nation's citizens to becomes fully employed. New advances in agriculture, technology and industry have brought the nation a long way, and it will continue to grow and change if appropriate capacity development policies are implemented effectively as time goes on. Ethiopia has improved greatly because of its economic growth and expansion in agriculture, industry, infrastructure building and tourism. According to Robert Dibie (2014:438) growth in infrastructure represents those types of capital goods that serve the activities of many industries included paved roads, railroads, seaports, communication networks, financial systems, and energy supplies that support production and marketing for industries within Ethiopia as well as other countries. Ikharehon (2007:5) contends that necessity for capacity building cannot be over emphasized in the matter of sustainable development. This is because for sustainable development to be realized in developing 
countries, such nations must be able to produce more skilled human capital and this can only be achieved by the government if it invests heavily in entrepreneurship and the acquisition of technical skills. The quality and relevant capacity building in developing countries should be such that it must help the related countries put in place machineries for sustainable development.

Francois Theron (2005) describe building block of development as a possible process in which to present a positive relation between top-down and bottom-up planning. Theron (2008) contends that building block of development model tends to show an appreciation for a social learning process, participation, empowerment and sustainable development partnership. The process helps both the change agent and the beneficiaries of development to conceptualize and contextualize the building block towards planning a development process. As a result, any micro-level development engagement should consider the value of a slow-fast and incremental process, following the principles embodied in the building blocks of development (Brown 1997; Conyers \& Hills 1990:17). Chamber (2005:15) pointed out that every capacity building process need congruence in institutional and personal change. In this regard, institutional and personal transformation should ideally interact and reinforce each other. Rondinelli (1993) and Esman (1991) requested developing countries to adopt a radical move towards participation, empowerment and diversity. Chamber (2005:18) considers this prescription as a shift towards pro-poor realism.

The social constructionist theory presents an argument that change initiatives do not come about as a due process following the crafting of strategy and policy (Lehne 2012; Boxer 2011). The theory stipulates that without effective implementation, even the most creative policy will fail (Porter 2006; Kraft and Furlong 2013:67). It also suggests that attending to members' value systems and identifications may be one way of improving the likelihood that an organization or government will productively co-evolve with natural and work environment.

According to Thomas Dye (2010:27) the lack of leadership could pose a major challenge and barrier to the implementation of any capacity building projects and sustainable policy. He suggested that in teaching about occupational safety and health as well as environmental issues there must be a commitment and dedication to the understanding of how political and public administration leaders deal with the implementation of public policies. Dibie (2014:431) contends that for public policy 
implementation to be successful public administrators and political leaders need to be able to inspire others to behave appropriately in order for these capacity building and environmental policies to be implemented as intended. The social constructionist theory could be used to argue that the capacity building measures policy was enacted and implemented in Ethiopia for the common good. Figure 1 shows the various components of a framework that will be used for capacity building.

Figure 1: Social Constructionist Theory Model

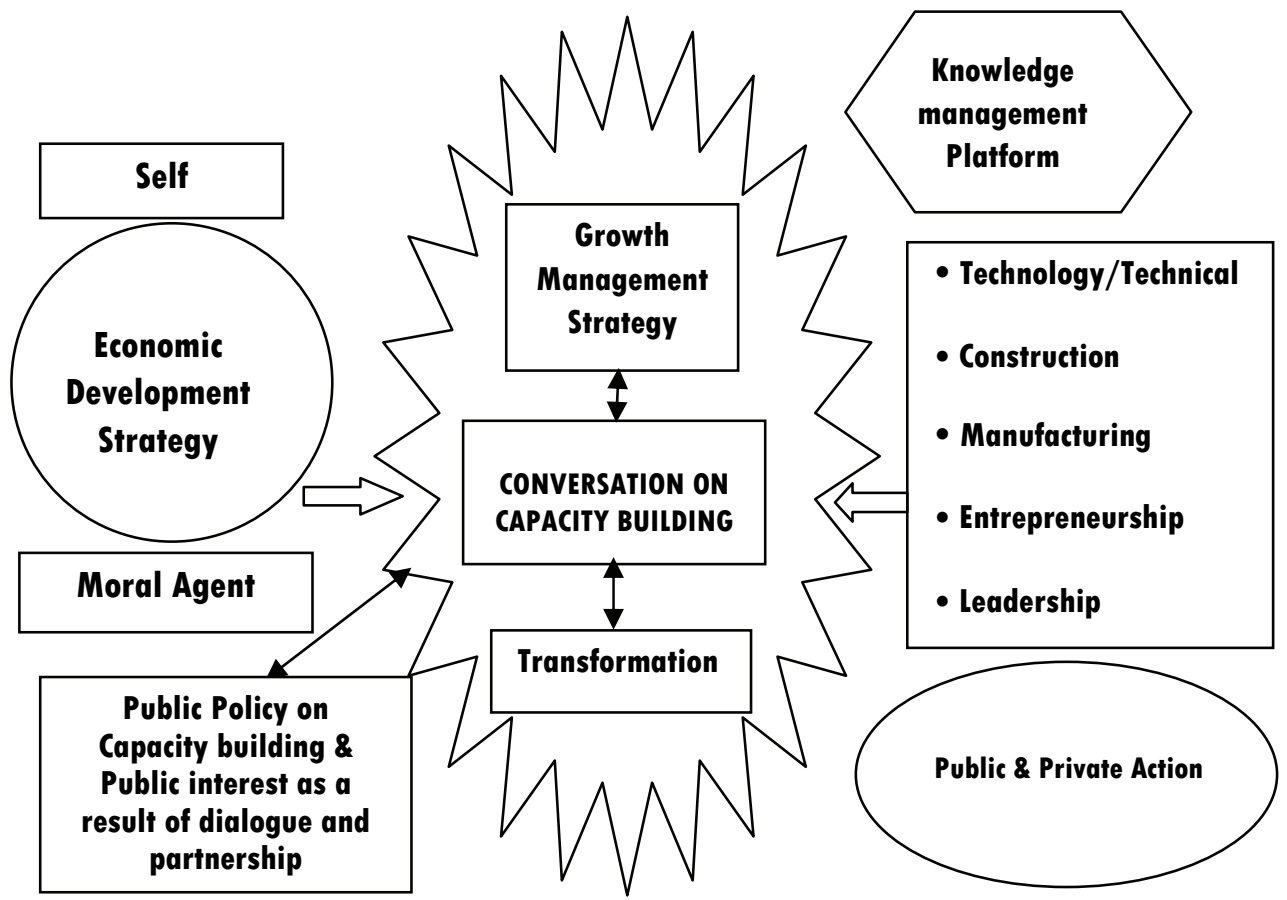

Source: Adopted from Boxer, Lionel. (2011). "Preparing Leaders for Sustainable Future." International Journal of Business Insights and Transformation, Vol. 3, (January), 34-43. 
Appreciating the interconnectedness of the several parts of the framework predicts that a change in one component will affect the other components. According to Dibie (2014) public policy should be the outcome that supports the public interest. Public administrators and political leaders must seriously consider the complexities of the public interest not only among themselves but in dialogue with a variety of stakeholders. Thus, conversation among stakeholders is the major instrument that could enable public policy towards the achievement of capacity building.

Figure 1 represents the concept of constructionist's theory. It is a representation of what happens when we engage in conversation. Figure 1 shows that the ideal platform for development is a partnership-in-planning approach. This should be a partnership through which the change agent as outsider closely collaborates with the beneficiaries of a particular program or project in all the stages of planning and implementing. It is continuously shown all over Africa that the change agent often leans towards a mechanistic top-down approach because they believe that it works better if the development process is driven from outside due to the poor knowledge and skills levels among grassroots (insider-out) participants.

The World Bank (2012) described capacity building as a process of change and the systematic management of transformation. It involves the transformation of peoples, institutional and society's capacity. Capacity building according to Chambers (2005:13) requires commitment, vision of leadership, viable institution and respective organizations, material, financial and skilled human resources. UNDP (2003) defined capacity building to cover human resources development and the strengthening of managerial systems, institutional development that involves community participation and creation of an enabling environment. Capacity building in the context of development implies a dynamic process which enables individuals and agencies to develop the critical social and technical capacities to identify and analyze problems as well as provide solutions to them. Azikiwe (2006) contends that capacity building entails the process by which an individual, irrespective of sex, is equipped with skills and knowledge they need to perform effectively and efficiently in their different callings. According to Olivier de Surdan (2005:31) and Francois Theron (2008) capacity development takes place at three different levels: (a) the individual level; (b) the organizational level; and (c) the societal level. These three levels are interlinked and interdependent. An investment in capacity development must design and account for impact at these multiple levels. 
A nation's focus on what development policies and investments work best to strengthen the abilities, networks, skills and knowledge base cannot be that of intervention. The bone of contention is that capacity building is about capable and transformational states, which enable capable and resilient societies to achieve their own development objectives over time. Ideally the transfer of knowledge should be in both directions whereby a mutually beneficial and empowering social learning process and a partnership in planning through which the change agent acts as a mediator between types of knowledge system. The challenge of capacity building is to see what responsible wellbeing might mean for all people, in their relation with themselves, with others, and with the environment. Figure two shows a reflection of capacity building impact.

Figure 2: Reflection of Capacity Building Impact

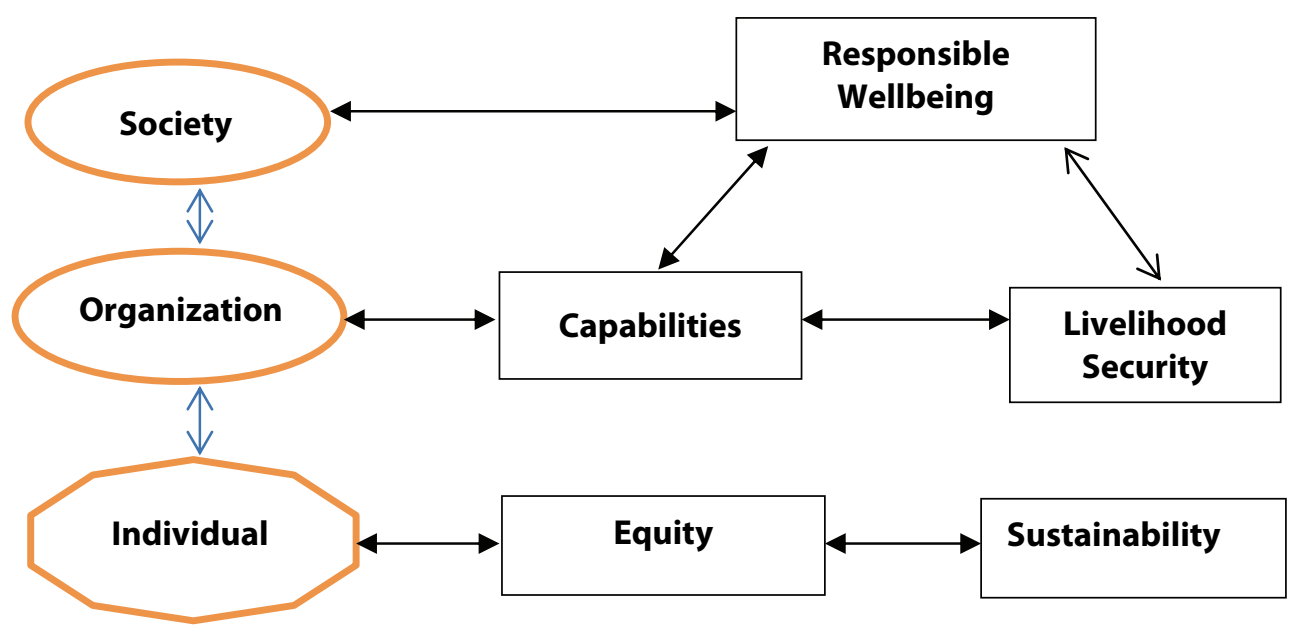

Adopted from Chambers (2005)

According to Dibie (2014:439) the major principles on which capacity building may create positive impact on people are in the areas of sustainability and equity. Capacity development is about whom, how and where the decisions are made, management takes place, services are delivered and results are monitored and evaluated. This is because the overarching ends are human well-being supported by capability and livelihood. Sustainability and equity as principles qualify livelihood to become livelihood security, and well-being to become responsible and sustainable. The question in the case of 
Ethiopia is: Do the beneficiaries experience a life-changing reality which builds their capacity, empowers them, and establishes honour dignity and self-esteem? The action research conducted in the country does not show total appreciation of this kind of reality.

Argyris and Schon (1978), Kolb et al., (1971) and Revans (1980) developed theories of learning which incorporate the possibility of learning at the organizational level. Kolb's (1971 and Revans (1980) contend that learning takes place when individuals critically reflects on their life experience, generalize from their reaction, and experiment with new behaviours, by constructing experience for further reaction. Revans' approach is particularly relevant to sustainable development, because it argues that organizations will survive and prosper in turbulent times only if they develop the ability to learn from their experience exceeds the rate of change (1991).

Many scholars have described the "five major economic goals that government should attempt to promote in their strategic development plans. These sustainable development goals include economic growth, low levels of unemployment, low levels of inflation, a positive balance of trade, and management of deficits and debt (Kraft and Furlong 2013; Mankiw 2012; Mandel 2012; Ferrell et al., 2011). Economic growth means an increase in the production of goods and services each year, and it is expressed as Gross Domestic Product (GDP). Stable prices or low levels of inflation or an increase in the cost to goods and services measured by the Customer Price Index reflects every change in the pricing goods and services. A positive balance of trade is an economic goal that positively reflects the role of Ethiopia in an international economy. In addition, full employment benefits might further galvanize the Ethiopian economy. If unemployment goes up the Governments will loss revenues because of the loss of taxes from pay cheques. Because the government will have increased expenses due to welfare, and unemployment expense paid to the workers (Mankiw 2012; Ferrel et al., 2011; Peters, 2013:63).

Governments have numerous strategic options at their disposal to try to influence the performance of the economy. Analysts believe that the two most popular options include fiscal policy and monetary policy. Other options include regulation and tax policy. The first policy that the Government of Ethiopia uses is fiscal policy. According to Chad Brooks' article, "What is Fiscal Policy" (2012), he observes that, one of the factors that helps determine the country's economic direction is fiscal policy. The government 
uses fiscal policy to influence the economy by adjusting revenue and spending levels. Fiscal policy can also be used in combination with monetary policy. There are two main tools of fiscal policy. These tools include taxes and spending. Chad (2012) contends that taxes influence the economy by determining how much money the government has to spend in certain areas and how much money individuals have to spend. For example, if the government is trying to spur spending among consumers, it can decrease taxes. A cut in taxes provides families with extra money, which the government hopes they will turn around and spend on other goods and services, thus spurring the economy as a whole (Brooks, 2012). Another tool that fiscal policy uses is spending. Spending allows for government money to spread to certain sectors (i.e., capacity building) that need technical skills and economic boost. Individuals who receive these dollars will have extra money and will hopefully spend it on other goods and services. It is crucial for governments to find the right balance and to make sure that the economy doesn't lean too far either way.

There are two types of fiscal policy: expansionary and contractionary. The first type, expansionary fiscal policy is designed to stimulate the economy. Expansionary fiscal policy is used during a recession and times of high unemployment or other low periods of the business cycle. It involves either the government spending more money, lowering taxes, or both. The goal is to place more money in the hands of the consumers so they can spend more and stimulate the economy. The second type, contractionary fiscal policy is used to decrease economic growth, such as when inflation is growing too rapidly. Contractionary fiscal policy also raises taxes and cuts spending. Fiscal policies are tied into the federal budget each year. The federal budget gives an overview of the government's spending plans for the fiscal year and how it plans to pay for that spending through either new or existing taxes.

The Monetary policy determines the amount of money flowing through the economy, and can affect the direction of a nation's economy. Monetary policy is set by the Central Bank of Ethiopia and influences the economic activity by controlling the country's money supply and credit. The Central Bank of Ethiopia can control monetary policy by fluctuating rates of interest and changing the amount of money banks must have in their reserves (Mandel, 2012; Mankiw 2012). The monetary policies goals are to encourage maximum employment, stabilize prices and moderate long-term interest rates. According to Mankiw (2012) and Mandel (2012) when implemented correctly, monetary policy 
stabilizes prices and wages, which in turn leads to an increase in jobs and long-term economic growth. For example the United States monetary policy plays a significant role not just in the economy as a whole, but in specific decisions consumers make, such as buying houses and cars, starting and expanding businesses and deciding to invest money (Brooks, 2012). The key to monetary policy is finding the perfect balance; if you let the money supply grow too rapidly it increases inflation, while letting it grow too slowly stunts economic growth.

Economic theory on employment and unemployment has contributed to the problem of youth unemployment in Ethiopia. The problems with supply and the demand sides of the labour market in the country as well the lack of a transparent labour market information systems have galvanized severe economic growth problems in Ethiopia. According to Schiller (2011) supply side factors such as demographic structure, education and training policies could affect the labour market outcomes in any nations' economy. Demand side issues including aggregate demand of the economy and the absorptive capacity of the economy for labour through development of enterprises and job creation institutions are potential factors that affect unemployment rate in any country (Schiller 2011; Lehne 2012). In addition, the ineffective labour market information system, the institutional and fiscal and monetary policies have major roles in the interaction of the supply and the demand sides of the labour market in Ethiopia (Mangozho, 2001 \& 2002). The literature review presented several arguments that unemployment often constitutes potential low economic growth. According to Ferrell et al (2011) the potential danger of not achieving economic growth lies in high unemployment and inflation rate among other factors. The Phillips curve represents the relationship between the rate of inflation and the unemployment rate. W. H. Phillips (cited in Mankiw 2012) believes that a consistent inverse relationship: when unemployment was high, wages increased slowly; when unemployment was low, wages rose rapidly (Mankiw, 2012; Hoover 2008).

The International Labour Organization (ILO) declaration on Social justice for fair globalization (2008) stipulated that an enabling environment for promoting employment is one in which individuals can develop and update the necessary capacities and skills they need to enable them to be productively occupied for their personal fulfilment and the common well-being. The quality and relevant capacity building in developing countries should be such that it must help the related countries put in place machineries for sustainable development. According to Anderson (2015) and Dibie (2014), in order to 
tackle the unemployment and capacity gap between basic education, vocational training, and the job market life-long, learning these factors are required: (1) skills provider and employers; and (2) skills development and industrial investment, trade, technology and environmental policies. Further, through institutions such as: (1) inter-ministerial mechanisms - linked to national development framework; (2) social dialogue; (3) skills forecasting and labour market information system; (4) value chain; (5) industrial clusters; (5) social inclusiveness; (6) maintaining employability of workers and sustainability of enterprises; (7) match demand and supply of skills; and (8) sustain a dynamic development process (Jones, 2001; Lehne 2012; ILO 2008). It could be argued therefore that skills development can improve employability of workers, productivity of enterprises and the inclusiveness of economic growth. Thus, capacity building is a fundamental human right as well as a key driver for economic growth. It is therefore considered a priority on the sustainable development agenda of Ethiopia.

The Government of Ethiopia has an obligation to seek new and even more effective ways of making tangible progress towards its sustainable development strategic policies. The attainment of the nation's sustainable development policies requires building organizational capacity (Anderson 2015; Kraft and Furlong, 2013). All too often the governments in the country, however, focus on creating new programs and keeping administrative costs low instead of building the organizational capacity necessary to achieve their aspirations effectively and efficiently (Dibie, 2014). The nation must change both its public administrators and those that fund them. It must also recognize that excellence in programmatic innovation and implementation are insufficient for government institutions to achieve lasting economic growth results. As a result, great programs need great organizations and capacity building measures behind them (Miller et al., 2014).

\section{Research Methodology}

The goal of this paper is to examine the nature of youth capacity building and unemployment in Ethiopia. The analysis utilized data derived through primary and secondary sources in Ethiopia. Primary research includes interviews in many cities and towns randomly selected from a government list for example, Addis Ababa, Jima Awase, Gambella, Bahir Dar, Gonder, Asela, Dese Gonder, Adama, Gimbi and Dire Dawa. Most of 
the primary data and information were derived from interviews. The open-ended, indepth and interactive interview approach gave the respondents the opportunity to discuss reasons for unemployment and capacity building issues in Ethiopia. Focus group discussions and in-depth interviews were useful to capture the respondents' voice, experience and interpretation of their experiences of the effectiveness of government capacity building policies.

On the other hand, the secondary data were derived through content analysis of government policy documents, annual reports produced by international agencies such as the International Labour Organization (ILO), United Nation Economic Commission for Africa and World Bank. Other data sources include Annual reports from the Central Statistical Agency of Ethiopia, the Ethiopian Investment Agency and the National Bank of Ethiopia. Staff members of government agencies, departments and nongovernmental organizations (NGOs) were interviewed to substantiate the cases in point. The findings support some of the arguments presented in the literature review. The central research questions are:

1) What is the nature of youth unemployment and capacity building in Ethiopia?

2) What are the social and economic problems associated with youth unemployment in Ethiopia?

3) In what ways have current government policies empowered youths to be entrepreneurs in Ethiopia?

4) What is the Government of Ethiopia doing to effectively implement its capacity building policies?

5) Are the fiscal and monetary policies adopted by the Government of Ethiopia effective in addressing the unemployment problems in the country?

6) What are the appropriate policies that the Government of Ethiopia could enact in the future to address youth unemployment?

\section{Analysis of Youth Unemployment Problems}

The environment in which change agents work also plays a part in determining how effective capacity building programs function or are implemented. The problem of unemployment basically arises from two essential dimensions of the labour market - the demand and supply sides of the market. On one hand, the demand side of the labour 
market is associated to the ability of the Ethiopian economy to generate employment opportunity for various skill categories. On the other hand, the supply side of the labour market deals with whether the current labour force in the country matches with the type of skills that the economy demands. In addition to the labour market, public and private institutions such as the governance of labour market-industrial relations and labour market services play significant role in employment promotion. This implies that an ineffective management of labour market institutions has also led to high unemployment in Ethiopia.

During the focus group meetings, the respondents revealed a number of factors and characteristics that they connect to their desire to contribute to the sustainable development process in Ethiopia as well as their sense of employability. As a result of the above understanding of individual employment and appropriate skills required, our respondents were able to transform their practice, perceptions and thinking of the role of citizens in Ethiopia.

Table 1 shows how they were able to break the social and economic stereotype regarding participation in the sustainable development process as well as what the role of the Government of Ethiopia in creating an enabling environment. The comments of ninety-six percent of the women respondents also indicate that they were ready to venture into male dominated careers if they were empowered by laws. They also indicated that if laws that support the principle of equality between men and women were enacted as a constitutional provision in Ethiopia, women would be more empowered to seek their professional dreams.

The following section provides a detailed discussion of the 1,336 statements made during the interview sessions. The interview findings show the gaps between employment of boys and girls. About 60 percent of the boys interviewed indicated that they had graduate from high school or vocational colleges and are employed in one form of private business or the other. In addition, 40 percent of the girls interviewed stated that they have not been able to find jobs. What is interesting is that only 20 percent of the respondents indicated that they like the job that they are currently doing. A total of 11 percent of the girls interviewed pointed out that they could not find jobs because the hiring managers preferred boys. Thus, there is consciousness to discrimination against women and girls in some industrial sectors in Ethiopia. This study has some refreshing revelations related to lack of appropriate equal employment 
opportunity policies in Ethiopia. It is interesting to note also that 55 percent of the female high school and some college graduates indicated that their culture and religion would not allow them to work in the hospitality and tourism industry.

Respondents in the interview session contend that the barriers to women's empowerment and social consciousness are tied to self-efficacy, lack of self-esteem, lack of public trust, lack of appropriate policies, and disrespectful treatment of women by their culture. Eighty percent of the respondent indicated that if women are to become fully integrated into the economic and social sphere of life in Ethiopia, certain amount of acculturation must occur. About sixty percent of the male respondent and seventy percent respectively of the female respondent indicated that the labour laws of the country have not been the most pertinent area of the policies for working young graduates. A total of 80 percent of the respondents stated that they do not know much of what the Government of Ethiopia was doing to encourage small business development in the country. They did not know how to secure funding to start their own business after acquiring the appropriate skills from vocation colleges or universities.

Table 1: Number of Statements made by Focus Group Question Respondents

\begin{tabular}{|l|l|l|l|}
\hline Employment Issues & Negatively Affected & Positively Affected & Total \\
\hline Constitutional Issues & & & \\
& & & \\
\hline Equality & 198 & 2 & 200 \\
\hline Human Rights & 151 & 49 & 200 \\
\hline Civil Rights & 170 & 30 & 200 \\
\hline Political Rights & 130 & 70 & 200 \\
\hline & & & \\
\hline Crime due to Unemployment & & & \\
\hline Theft & 25 & 175 & 200 \\
\hline Prison term served & 120 & 80 & 200 \\
\hline Prostitution & 108 & 92 & 200 \\
\hline Other Forms of crimes & 125 & 75 & 200 \\
\hline & & & \\
\hline Family Relations & & & 200 \\
\hline Girls Forced to Marriage & 50 & 150 & 200 \\
\hline Divorce & 180 & 20 & 200 \\
\hline Child Custody and Guardianship & 200 & 0 & \\
\hline
\end{tabular}


The Dichotomy of Capacity Building and Unemployment in Ethiopia 41

\begin{tabular}{|l|l|l|l|}
\hline Reproduction & 102 & 98 & 200 \\
\hline & & & \\
\hline Economic Issues & & & \\
\hline Credit to start business & 182 & 18 & 200 \\
\hline Ownership \& Control of Property & 180 & 20 & 200 \\
\hline Inheritance & 185 & 15 & 200 \\
\hline & & & \\
\hline $\begin{array}{l}\text { Effectiveness of Government } \\
\text { Policy }\end{array}$ & & & \\
\hline Provision of Training & 140 & 60 & 200 \\
\hline Opportunities for Employment & 178 & 22 & 200 \\
\hline Protective Legislation & 162 & 38 & 200 \\
\hline Social Entitlements & 182 & 18 & 200 \\
\hline Wages & 50 & 150 & 200 \\
\hline Working Conditions & 120 & 80 & 200 \\
\hline $\begin{array}{l}\text { Awareness of Capacity building } \\
\text { policy }\end{array}$ & 90 & 110 & 200 \\
\hline
\end{tabular}

Source: Derived from Focus Group Meeting 2009-2012

Respondents unanimously (ninety-three percent) reported that it is more difficult for women than men to get promoted in some professions. This is largely because some professions are dominated by men and few women who are employed in such organizations are in nonprofessional career positions. Furthermore, some senior manager or directors have very little regard for women and that makes it difficult for them to be promoted. The respondents contend that since the socio-cultural environment is highly male dominated and discriminatory, if a woman does not build her own confidence and competence, and does not demand her rights she might be forced out of her position. Thus, a constitutional men and women equality provision would enable women to be focused and effectively address discrimination issues.

\section{The Ethiopian Demand Side of Labour Market Issues}

According to the Ethiopia Central Statistics Agency, report (2012), the agricultural sector is the dominant sector in the Ethiopian economy because it contributes over 41 percent of the nation's Gross Domestic Product (GDP). The agricultural sector also contributes 60 percent of Ethiopia's exports, and is the major employer of approximately 83.5 percent 
of the country's population. In addition, the agricultural sector in Ethiopia is the major employer of the rural population. As a result, job opportunity for urban youth in agricultural sector is limited. The second largest contribution to the national GDP of Ethiopia comes from the service sector (Gebeyaw and Chofana, 2012:5). Recent reports revealed that the contribution of the service sector to Ethiopian gross domestic product is about 46 percent (Ethiopia Central Statistics Agency, 2012). Though the service sector of the economy has shown flamboyant performance with regard to its contribution to the GDP in recent years, it could not generate significant employment opportunity and neither is it paying as does the industrial sector. Figure 3 shows the sectorial gross domestic product (GDP) Composition of Ethiopia.

\section{Figure 3: Sectorial Gross Domestic Product (GDP) Composition}

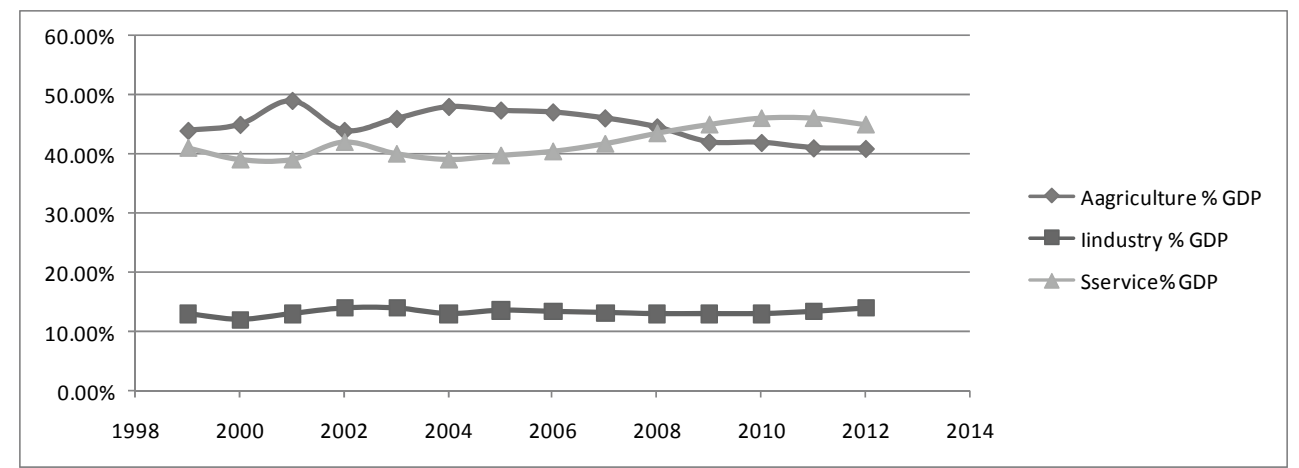

Source: National Bank of Ethiopia, 2012.

The industrial sectors contribution is very minimal with about $13 \%$ comparative to the two dominant sectors in the Ethiopian economy. This indicates significant structural weakness of the economy. Employment opportunity for urban youth is directly related to the development of the industrial sector of the economy. The low level of development in the industrial sector of the economy therefore is one of the major issues that explain urban youth unemployment problem. Figure 4 shows the sectorial gross domestic product (GDP) growth rate of Ethiopia. 
Figure 4: Sectorial Gross Domestic Product (GDP) Growth Rate

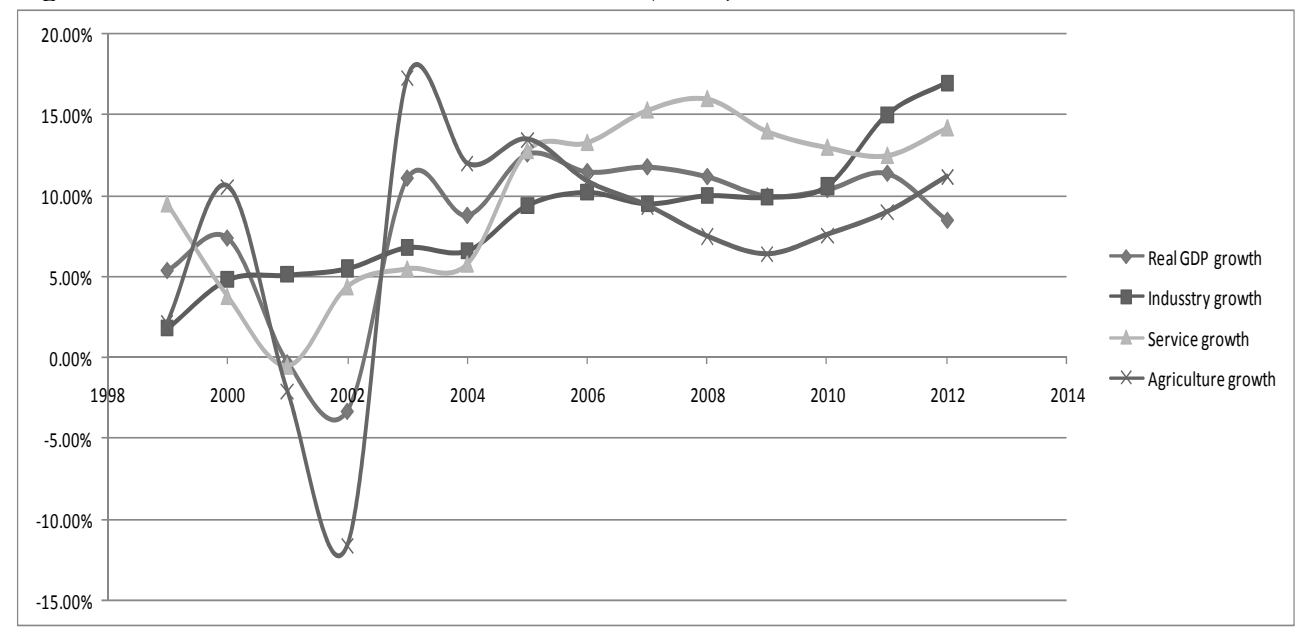

Source: National Bank of Ethiopia, 2012

Figure 4 shows data from the National Bank of Ethiopia. The figure shows that since 2007 the service and the industrial sectors have outgrown the agricultural sector constantly. While most of the Ethiopia's growth potential appears to come from the industry and services sectors, the government has chosen to emphasize the agricultural sector in pursuing economic growth under agricultural lead industrialization policy parameters. Between 2004 and 2012, the service sector exhibited remarkable performance (far more than planned); however, the industrial sector under-performed and even failed to meet its five years base target. Thus, the low share of the manufacturing sector, a very important sector in transforming an economy, is a major concern for the Ethiopian policy makers as in most African economies. Several scholars have attributed the demand side problems of the labour market in the African economies to be the result of weakness of the economies, saturated public services and small private sector bases that are unable to employ large numbers of people (Schiller 2011; Mankiw 2012; Adebayo 1999; Rondinelli 1993; United Nations Economic Commission for Africa (UNEC,) 2011).

A study by the Ministry of Education in Ethiopia in 2002 reveals that the education system in the country has failed to promote vocational and technical trainings. This flaw in the nation's educational system has negatively affected the level of cognitive skills of students and their aspiration for success. According to the United Nations Economic 
Commission for Africa (2011), this inadequate vocational training skills problem is common to most African countries. Therefore it could be argued that the negative correlation between educational systems and the technical skills needed in the labour market is one of the noticeable causes of youth unemployment in Sub-Saharan African countries including Ethiopia. Table 2 shows unemployment rate by gender and educational level in Ethiopia.

Ethiopia has documented employment policy and the Ministry of Labour and Social Affairs is in charge of the collection, analysis, documentation and distribution of the labour market information in the country. Congruously, the Ministry of Labour and Social Affairs has been publishing labour market information bulletin for dissemination of the labour market information to stakeholders on annual basis. The publication incorporates varieties of information collected and analyzed from such sources as census reports, labour force survey, employment survey and educational statistics of the Federal Ministry of Education. Table 3 shows the relationship between employment and population ratio in Ethiopia.

Statistics in table 3 show that 49.4 percent of the population were employed at the time of the survey at national government level and 45.9 percent at the Addis Ababa city level. The differentials of employment to population ratio by sex illustrate that 60.2 percent of males and 40 percent of females were employed in 2011 at country level. However, the figures are lower at Addis Ababa level, i.e., 58.5 percent for males and 35.3 percent for females.

Periodical analysis of employment to population ratio reveals that the percentage of the employed population increases overtime. The size of the employed population increased from 47.5 percent in 2009 to 48.2 percent in 2010 and reached 49.4 percent in 2011. This is true for males and females during the same survey period. However, the data shows that unemployment is higher in Addis Ababa when compared to the national government level rate. The ratio of employed female is significantly lower when compared to their male counterparts at national and in the Addis Ababa city levels. 
Table 2: Unemployment Rate by Gender and Educational Level

\begin{tabular}{|l|c|c|c|}
\hline \multirow{2}{*}{ Educational Status } & \multicolumn{3}{|c|}{ Unemployment rate } \\
\cline { 2 - 4 } & Total & Male & Female \\
\hline Illiterate & $15.2 \%$ & $7.7 \%$ & $18.5 \%$ \\
\hline Literate & $18.1 \%$ & $11.8 \%$ & $26.3 \%$ \\
\hline Educational Level & & & \\
\hline Pre-school & $14.5 \%$ & $2.7 \%$ & $21.9 \%$ \\
\hline Non Formal & $15.0 \%$ & $9.6 \%$ & $23.0 \%$ \\
\hline Grades 1-8 & $16.8 \%$ & $9.6 \%$ & $25.1 \%$ \\
\hline Secondary not completed* & $20.8 \%$ & $14.9 \%$ & $30.3 \%$ \\
\hline Secondary Education Completed** & $24.8 \%$ & $16.6 \%$ & $36.3 \%$ \\
\hline $\begin{array}{l}\text { Preparatory } \\
\text { Certificate Completed*** }\end{array}$ & $22.0 \%$ & $18.4 \%$ & $18.4 \%$ \\
\hline \begin{tabular}{l} 
Diploma Completed \\
\hline Degree and above Completed
\end{tabular} & $19.2 \%$ & $12.6 \%$ & $23.7 \%$ \\
\hline$*$ Includes those who completed grade 9 in the new devised curriculum and grade 9-11 in old \\
$\begin{array}{l}\text { curriculum } \\
* * \text { Includes those who completed grade } 10 \text { in the new devised curriculum and grade } 12 \text { in old } \\
\text { curriculum } \\
* * * \text { Includes TVET and any certificate above grade } 12 \text { in the old curriculum. }\end{array}$ \\
\hline
\end{tabular}

Source: Ethiopia Central Statistical Agency urban employment unemployment survey 2012

Table 3: Employment to Population Ratio

\begin{tabular}{|c|l|l|l|l|l|l|}
\hline Region & Sex & $\mathbf{2 0 0 4}$ & $\mathbf{2 0 0 6}$ & $\mathbf{2 0 0 9}$ & $\mathbf{2 0 1 0}$ & $\mathbf{2 0 1 1}$ \\
\hline \multirow{3}{*}{ Country level } & Both sexes & 42.6 & 48.8 & 47.5 & 48.2 & 49.4 \\
\cline { 2 - 7 } & Male & 51.6 & 58.5 & 59.0 & 58.5 & 60.2 \\
\cline { 2 - 7 } & Female & 34.6 & 40.7 & 37.3 & 39.0 & 40.0 \\
\hline \multirow{2}{*}{ Addis Ababa } & Both sexes & 42.9 & 44.7 & 44.9 & 47.2 & 45.9 \\
\cline { 2 - 7 } & Male & 54.0 & 56.0 & 57.6 & 57.9 & 58.5 \\
\cline { 2 - 7 } & Female & 33.3 & 35.6 & 34.0 & 38.0 & 35.3 \\
\hline
\end{tabular}

Source: Ethiopia Central Statistics Agency, 2011 
Ethiopia has the largest youth population in Sub-Saharan Africa (World Bank, 2007). More than half of its population is under the age of 25, and 20\% are between 15 and 24 years old. Furthermore, this proportion is steadily increasing, having grown from $14 \%$ in 1984 to about $20 \%$ in 2005 and is still growing. Table 4 shows the trend of urban youth unemployment by sex in Ethiopia.

Table 4: Trend of Urban Youth Unemployment by Sex

\begin{tabular}{lcccccc}
\hline Year & \multicolumn{3}{c}{ Country level } & \multicolumn{3}{c}{ Addis Ababa } \\
\cline { 2 - 7 } & Male & Female & Total & Male & Female & Total \\
\cline { 2 - 7 } 1999 & 18.3 & 34.0 & 26.4 & 28.0 & 48.2 & 38.1 \\
2003 & 26.7 & 42.7 & 31.6 & 21.2 & 43.7 & 32.1 \\
2004 & 23.3 & 38.7 & 31.5 & 30.3 & 32.6 & 31.1 \\
2005 & 19.4 & 32.9 & 26.9 & 32.9 & 42.2 & 37.7 \\
2006 & 17.1 & 28.0 & 22.7 & 31.2 & 38.9 & 35.1 \\
2009 & 17.4 & 33.9 & 26.0 & 24.3 & 32.1 & 28.0 \\
2010 & 16.6 & 31.6 & 24.5 & 17.9 & 36.1 & 26.9 \\
2011 & 16.5 & 30.3 & 23.7 & 17.3 & 33.7 & 25.1 \\
\hline
\end{tabular}

T-test for equality of average youth unemployment b/n country level \& Addis Ababa at 5 $\%$ significance level $(\mathrm{sig})=0.50$.

T-test for equality of average unemployment between and female youth at country level \& Addis Ababa at 5 percent significance level $(\mathrm{sig})=.006$.

\section{Source: Ethiopia Central Statistics Agency, 2011}

The youth in urban areas of Ethiopia are characterized also by persistently high unemployment (World Bank, 2007). As noticed by Nebil et al., (2010:17), without opportunities for today's youth to earn a living, poverty will persist through the next generation. Therefore, the attention by all stakeholders particularly, private sector, government and NGOs and other civil society organizations in an integrated manner is indispensable for necessary measures to be taken in the country. Table 5 shows the trend of urban youth unemployment at country level and in Addis Ababa.

In the previous 8 years from year 2003 to 2011, even though urban youth unemployment shows certain rate of decrease, the female youth unemployment rate is highly pronounced when compared with their male counterparts both at national and in the Addis Ababa city levels. If one analyzes the total urban youth unemployment, it will 
show a higher rate at the Addis Ababa city than at the national government level during the past 8 years. It is also noticed that the highest unemployment is pertinent to female youth in the city than their male counterparts. From all these facts, we can understand that the female youth are more vulnerable to unemployment at the national as well as in the Addis Ababa city levels than the male youth. The average difference of the urban youth unemployment rate between national and the Addis Ababa city levels, as well as male and female youth are statistically significant at 5 percent level. Table 5 shows the sectorial gross domestic product (GDP) composition of Ethiopia.

Table 5 shows that on average 59 percent of the youth in the country were jobless for less than 13 months from between 2004 and 2011. Besides, unemployed youth, who were without jobs for 96 months and above, account for an average of 12 percent during this period. In addition, those who stayed without work for 13-24 months and 2595 months accounted for an average of 13 percent and 15 percent respectively. The number of females who were jobless for more than 13 months was greater than their male counterparts during all unemployment periods.

Table 5: Urban Unemployment Duration

\begin{tabular}{|c|c|c|c|c|c|c|}
\hline & \multirow[t]{2}{*}{ Survey period } & \multirow[t]{2}{*}{ Sex } & \multicolumn{4}{|c|}{ Duration of Unemployment (in Months) } \\
\hline & & & $<=12$ & $13-24$ & $25-95$ & 96 and above \\
\hline \multirow{12}{*}{ Country level } & 2004 & Total & 50.4 & 16.1 & 21.4 & 10.5 \\
\hline & & Male & 56.2 & 15.3 & 19.4 & 7.1 \\
\hline & & Female & 47 & 16.6 & 22.6 & 12.4 \\
\hline & 2009 & Total & 54.1 & 13.4 & 15.8 & 15.2 \\
\hline & & Male & 60.8 & 12.2 & 13.7 & 13.1 \\
\hline & & Female & 51.0 & 14.0 & 16.8 & 16.2 \\
\hline & 2010 & Total & 70.1 & 10.1 & 11.3 & 8.4 \\
\hline & & Male & 72.6 & 10.2 & 10.1 & 6.9 \\
\hline & & Female & 68.9 & 10.0 & 11.8 & 9.1 \\
\hline & 2011 & Total & 61.2 & 12.5 & 12.5 & 13.8 \\
\hline & & Male & 66.7 & 12.7 & 11.4 & 9.3 \\
\hline & & Female & 58.2 & 12.5 & 13.1 & 16.1 \\
\hline & 2003 & Total & 44.4 & 16.2 & 22.4 & 17.0 \\
\hline & & Male & 18.6 & 6.0 & 7.5 & 4.0 \\
\hline & & Female & 25.8 & 10.1 & 14.9 & 13.0 \\
\hline
\end{tabular}


48 Africa's Public Service Delivery \& Performance Review

\begin{tabular}{|c|c|c|c|c|c|c|}
\hline \multirow[t]{9}{*}{ Addis Ababa } & 2004 & Total & 42.7 & 16.4 & 25.2 & 15.7 \\
\hline & & Male & 19.9 & 7.1 & 10.2 & 5.0 \\
\hline & & Female & 22.8 & 9.3 & 15.0 & 10.7 \\
\hline & 2006 & Total & 52.5 & 14.6 & 22.1 & 10.8 \\
\hline & & Male & 22.7 & 5.5 & 7.4 & 3.2 \\
\hline & & Female & 29.8 & 9.1 & 14.7 & 7.6 \\
\hline & 2009 & Total & 47.0 & 14.8 & 17.8 & 20.4 \\
\hline & & Male & 17.6 & 5.0 & 5.4 & 6.6 \\
\hline & & Female & 29.4 & 9.8 & 12.5 & 13.8 \\
\hline
\end{tabular}

Source: Ethiopia Central Statistics Agency, 2011

In Addis Ababa, 47 percent of the unemployed youth in the city had been jobless for less than 13 months from 2003-2009. The number of the youth who had been without jobs for 96 months and above, accounted for 16 percent during the survey periods in Addis Ababa. Members of the youth in the city who were unemployed for 13-24 months and 25-95 months respectively accounted for 15.5 percent and 22 percent. During all unemployment periods, the female youth were found to be the biggest jobless groups in the city. From this we can deduce that it takes a longer period for females in urban areas than the male counterparts to find employment.

\section{The Ethiopian Supply Side of Labour Market Issues}

To supplement the demand side of the labour market the government of Ethiopia introduced specific and youth targeted programs. One of such programs is the Cobblestone Project in urban Ethiopia which was initiated by the Engineering Capacity Building Program supported by the German Development Cooperative (GTZ). Since 2007, the Engineering Capacity Building Program has been training the youth in traditional crafting of cobblestone paving with the dual objective of creating jobs for youth and creating clean, attractive pavement roads in Ethiopian towns. It is based on the principle of local resource utilization in a labour intensive manner to pave roads and public spaces using environmentally amicable approach adopted from the German experiences. The project created jobs for the youth organized to operate Micro and Small Enterprises. This means construction of pavements in towns and cities enabled creation of new Micro and Small Enterprises thereby boosting housing investment. Available evidence shows that the project has resulted in the creation of more than 2,000 Micro and Small 
Enterprises and employed more than 90,000 youth in urban areas of Ethiopia by the end of 2011.

The Ethiopian Government has also made a number of efforts to address the unemployment problems faced by the urban youths because of the deficiency in the supply side of the labour market. As discussed earlier in the supply side problems of the labour market, the youth are challenged due to unemployment because of the mismatch between their skills and the skill the economy requires. The most noticeable reaction from the government to this problem was the policy reform introduced to rejuvenate the education system of the country to transform the century long theory oriented education into practice orientation and skills development. Up to the middle of the 1990s the orientation of the education system of Ethiopia was on theory rather than development of skills essential for effective practical exercise and entrepreneurial innovation.

Comprehensive education system reform was introduced in 1994 with due consideration of the deficiency in the previous education system. The phases of education cycle classification in the previous system were as follows:

- grades 1 to 6 are primary school;

- grades 7 to 8 junior secondary school;

- grades 9 to 12 secondary or high schools.

At the end of the $12^{\text {th }}$ grade students were given Ethiopian school leaving certificate examination to qualify for tertiary education. But a few of the examinees seek admission to study in a university study owing to the limited number of higher learning education institutions leaving the rest without opportunity for higher level skill development. According to urban employment survey by the central statistical agency in March 2012 those with general education are substantially victims of unemployment.

Amid the education sector reform Ethiopia has recorded remarkable development in access to primary education and literacy. There has also been evidence for significant improvement in access to primary education and literacy across Africa in the last decade (United Nations, 2010). According to the United Nations 2010 Millennium Development Goals Report, the net primary education enrolment rate in the Central, Western, Eastern and Southern African regions combined increased from 58 percent in 1999 to 76 percent in 2008, while in North Africa, it increased from 86 percent in 1999 to 94 percent in 2008. However, the increase in primary education enrolment rates has not necessarily been followed by an equivalent increase in secondary and tertiary education rates, 
especially for young women and girls. According to African Youth Report 2011 when it comes to tertiary education among youth populations in Africa, the gross enrolment rate for tertiary education level is very low. The pattern for Ethiopia is similar as the increase in primary education enrolment has not been accompanied by equivalent rise in secondary and tertiary education enrolment. The participation of women and young girls is significantly lower at the tertiary level compared with the participations in primary education. Increased provision of post-primary education could provide the youth with the hard and soft skills that will enable them to compete effectively in the labour market both domestic and global. This education deficit particularly affects socially excluded youth people especially young women. Ethiopia like many African countries has achieved gender parity at the primary education level. However, disparity remains significant, especially at the tertiary education level.

The new education system introduced in Ethiopia after the reform has been more progressive. Only those who scored qualifying results on the national examination offered at the end of the tenth grade are promoted to the preparatory schools. Those who do not achieve the necessary results for admission to the preparatory schools are provided with the opportunity to pursue formal education thorough Technical, Vocational Education and Training (TVET) which ranges from one to five years based on the level of competency the trainees want, and the nature of the field of study chosen. For this purpose a great number of polytechnics and technical training institutes were established to provide technical training in different trades and at various levels in a bid to strengthen the employability of the youth. This is the landmark departure of the current education system from the previous education programs of the country in which most of the secondary school graduates remains helpless due to lack of better and demanded skills. The positive impact of the Technical, Vocational Education and Training programs in enhancing employability of the youth in Ethiopia is documented in various studies. One of such studies for instance is by Guarcello and Rosati (2007) which showed that the impact of participating in training programs increases the probability of being employed by $25 \%$ in urban areas of Ethiopia and by about $13 \%$ in rural areas.

In a bid to improve the employability of the youth the government has been investing substantial portion of the public budget to the expansion of universities that accept qualified candidates from the preparatory schools. There have been enormous achievements with this policy. The number of universities just like the polytechnics and 
technical training institutes has been considerably increased from as low as 2 in 1991 to 31 in 2012. Moreover, the government devised modes of linkage between higher education institutions and the industry as well as initiated curricula reforms to insure relevance of higher education to Ethiopian economy. In spite of all these efforts, the fact that the economy could not absorb the graduates and unemployment started to challenge the literate is evident (Ethiopian Central Statistics Agency, 2012). This is partly attributable to the lower quality of education, and of course to the mismatch in skills desired by the economy and skills embedded in the graduates. The lower quality of education is because of the capacity constraint of the Government of Ethiopia to effectively pursue the expansion of access to education and assurance of the quality of educational programs. However, the government has shown its commitment to ensure the quality of education in an institutionalized approach and established Higher Education Relevance and Quality Agency (HERQA) affiliated to the Ministry of Education so as to enforce quality standards of higher education to remedy the quality problems.

The failure to encourage the citizens to participate in the planning and implementation of the policy in inner city redevelopment programs was partially because of lack of comprehensive strategic planning. This was also due the lack of political commitment by the government. It is understandable that the lack of resettlement policy framework could create confusions and complication as to how to deal with the cases. However the country's governance system is guided by a constitution that incorporates stipulations for citizen's rights to be adequately consulted concerning policies and projects affecting their community (Federal Democratic Republic of Ethiopia, 1994). This constitution also states that the government has the duty to hold land as an agent of the people. The provisions in the constitution hence imposed legal obligations that would have forced the City Administration to consult with the public. Article No. 44 subarticle 2 of the same constitution stipulates that all persons who have been displaced or whose livelihoods have been adversely affected as a result of government programs have the right to commensurate monetary or alternative means of compensation, including relocation with adequate government assistance. The compensations provided in the above cases were not according to the law of the country. In addition, relocated people were provided with replacement housings or plot of land for construction of houses (Abebe \& Alemu, 2013). In addition to its domestic laws, Ethiopia has also ratified and adopted Universal Declaration of Human Rights (UDHR); International Covenant for 
Economic, Social and Cultural Rights (ICESCR) that prescribe avoidance of forced eviction and proper participation of the affected group in planning and implementation of development induced resettlement.

It seems that the Government of Ethiopia may realize that they could afford the cost of non-participatory resettlement of original slum dwellers for inner city slum redevelopment programs. The government has consolidated its effort and issued resettlement plan in a view to guide the programs in the process of inner urban redevelopment in 2008 as mentioned earlier. The first pragmatic test against the implementation of this policy framework was the redevelopment project of Lideta Firdbet one out of the fourteen planned inner city renovation areas followed by Bole, Sengatera and Aratkillo sites (Abebe \& Alemu, 2013). In these cases there has been enormous improvement in the participation of the relocated original dwellers at least in sufficiently consulting them in the planning and implementation of the inner city redevelopment programs.

On one hand, there has been documented evidence that the relocated residents were not sufficiently compensated even in these cases. On the other hand, the project did not pay removal and transportation cost for the residents, though their representative committee demanded it. This implies that there is failure from the government in practical application of the legal provisions dictated to protect citizens' rights (Abebe \& Alemu, 2013). Further, the integration of the employment strategy to Urban Housing Development Policy has contributed to the creation of employment for previously unemployed urban youth (Woldehanna et al., 2008; Woldegebriel, 2011). The integrated urban housing development program ultimately targets the unemployed poor particularly the unemployed youth, in that the Micro and Small Enterprises in the construction sector tend to be labour intensive and employ low skilled workers. The participating Micro and Small Enterprises are usually established by youth who either graduated from a TVET or have had certain experience in the construction sector. The federal as well as the regional housing development offices provide different forms of assistance to the firms participating in the program. According to UN-Habitat (2011), the program commissioned in 2004 set up an ambitious goal of constructing 400,000 low cost houses, create job opportunities for 200,000 people, and promoted more than 10,000 Micro and Small Enterprises all over the country between 2005 and 2010. By 2010, the program had constructed 171,000 houses, created 176,000 new jobs, boosted 
the technical capacity of the construction sector, and enhanced the number and capacity of Micro and Small Enterprises newly created in Ethiopia (Ministry of Finance and Economic Development, 2012).

Thus, the process of urban reconstruction tend to fail to enhanced sufficiently participation in terms of the involvement of the displaced slum dwellers in planning and implementation in the redevelopment of inner urban areas. The lack of political commitment from the political leadership and defective capacity of the management are the basic contributory factors to the failure of the government to adhere to the standard operating procedure and legal provision of Ethiopia. In addition, some of the millions of unemployed urban youth in Ethiopia enjoyed the job opportunity provided by the urban housing projects and inner city redevelopment programs while original dwellers have been relocated to better housing conditions. Figure 4 shows the trends in the Government of Ethiopia Spending 1975 and 2011.

Private sector development is very important in every civilized society especially in capitalist's economic system. The recent development in Ethiopia also follows this pattern. In transition economies like the Ethiopian economy the development of the private sector requires support from the government (Dibie, 2014). Policies conducive to enhancement of the productivity of the private sector are important for this purpose. Equally important is the improvement of the linkage between the formal and informal sectors of the economy. The prevalence of informal economic activities is natural in Ethiopia as it is in transition economies. That means improving the complementarities between the informal and formal sectors of the economy can enlarge the business activities making more job opportunity. 
Figure 4: Trends in the Government of Ethiopia Spending

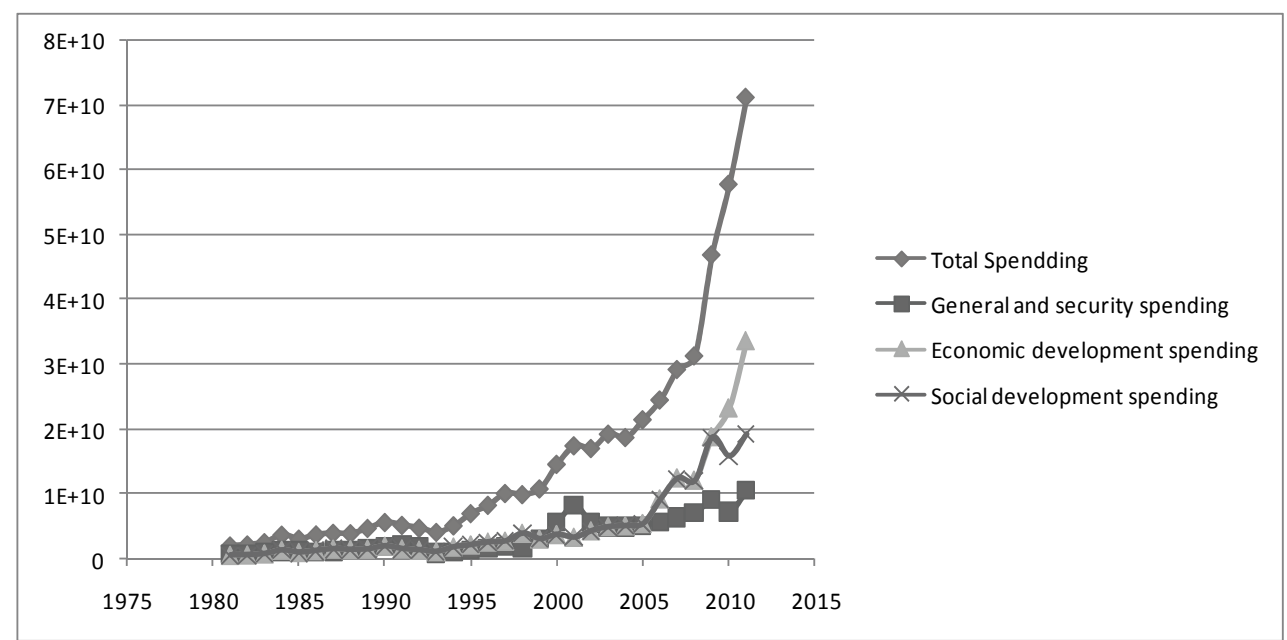

Source: Ministry of Finance and Economic Development, 2012

The policy environment of the pre 1991 Ethiopia significantly restricted private sector investment if not considered totally banned under the Marxist-Leninist social policies of that regime. In that regime, the maximum capital investment allowable for private owners was limited to $\mathrm{Br} 250,000$ (Ethiopian currency). With the complete demise of the socialist era in 1991 there has been significant economic reform measures undertaken to make the business environment congenial to entrepreneurship and private sector investment. The government implemented extensive deregulation and liberalization policies due to proactive actions. The aim of this government initiative is to establish a cordial business environment for the promotion of private sector investment. The government has been providing supports of diverse form of entrepreneurs and industrialists that yielded significant and progressive development in the promotion of private investment both domestic and foreign sphere. This supports mainly include provision of free land lease, subsidized credit services, reduction of tax rates, and tax relief for specified period of time, training services and more importantly business development services to encourage the achievement of the flourishing Micro and Small Scale Enterprises (Lahne, 2006). To curb the unemployment problem in urban areas the government has been providing effective supports to the youth interested in operation 
of micro and small enterprises on individual as well as group bases (Abebe \& Alemu, 2013).

Cognizant of the social and political consequences of youth unemployment, the government has also designed and implemented programs which targeted job creation for the youth over the last decade. The most noticeable policy actions were the introduction of Micro and Small Businesses Development Strategy and Industrial Development Strategy with the purpose of promotion of private sector development so that it plays significant role as a mechanism for economic growth and development. Since the Micro and Small Enterprises Development Strategy was crafted in 2004, the youth has been encouraged to enter into the program in an organized way with special support rendered from the government. The support includes provision of entrepreneurship and business management training; mutual guarantee credit services through micro finance institutions, market linkage services, relevant technology research, business development services and basic infrastructure deemed necessary for their operation. The government has shown its commitment to continue supporting the development of Micro and Small Enterprises in an institutional and coordinated approach. To this end the government established Federal Micro and Small Enterprises Development Agency and state governments stepped in by establishing similar agencies at regional levels. Ethiopia's policy of generating employment for the youth through enhanced skills development in the economically active population is similar to what is in practice in its counterparts of Sub-Saharan African economies (Dibie, 2014).

As part of the efforts to boost job opportunities for young people, countries such as South Africa, Kenya, Tanzania and Tunisia have developed young entrepreneurship programs and business start-up schemes supported by Small Business Development Organizations, which provide technical skills for new businesses (United Nations Economic Commission for Africa 2011). Another strategy used by other African economies not introduced by Ethiopian policy makers so far is the provision of incentives to firms for the hiring of young people. Such efforts have yielded some positive results; for example, 1.27 million jobs were created in Tanzania over the last three years as a result of these programs according to the evidence from the fact sheet of United Nations Economic Commission for Africa (2011).

The implementation of Micro and Small Businesses Development Strategy and Industrial Development Strategy has recorded enormous achievements in creation of 
employment opportunity for the youth in urban areas. It has benefited millions of youth in Ethiopian urban areas since its inception. Statistical evidence from the Federal Micro and Small Enterprises Development Agency revealed that the sector created employment opportunity for more than 1,150,000 unemployed youth in 2011 in Ethiopian urban areas. The Micro and Small Enterprises Development Agency has managed to achieve encouraging results in supporting the development of enterprises that are employment intensive so far. There are large numbers of micro and small scale enterprises that have graduated from their original level and transformed to medium scale industries. This, on one hand, could galvanize the successful support rendered from the government to the development of the sector. On the other hand, the capacity of the sector in employment generation and poverty reduction is not satisfactory. However, critics argue that the micro enterprise operators are developing dependency syndrome being locked in to the market linkage established by the government. Although the sector has shown its contribution to economic growth and development, there are number of constraining factors that hinder its growth. The basic constraining factors are associated with inadequacy of the provision of working premises, prototype development trainings, and infrastructure and credit facilities (Kibru, 2012). These constraining factors explain the challenges of youth employment in Sub-Saharan African economies. According to the United Nations Economic Commission for Africa (2011), barriers to the creation and development of business opportunities, particularly in gaining access to financial, physical and social capital are basic problems for job creation for the youth. This implies that periodic evaluation of the working policies and strategies with the aim of innovative amendment is vital to exploit the contribution of the private sector employment creation and poverty reduction. Table 6 shows the number and investment capital of approved projects by ownership. 
The Dichotomy of Capacity Building and Unemployment in Ethiopia 57

Table 6: Number and Investment Capital of Approved Projects by Ownership

\begin{tabular}{|c|c|c|c|c|c|c|c|c|}
\hline \multirow[b]{2}{*}{ Fiscal Year } & \multicolumn{2}{|c|}{ Domestic projects } & \multicolumn{2}{|c|}{ Foreign Projects } & \multicolumn{2}{|c|}{ Public Projects } & \multicolumn{2}{|c|}{ Total Projects } \\
\hline & $\begin{array}{l}\text { No. } \\
\text { Projects }\end{array}$ & $\begin{array}{l}\text { Investment } \\
\text { Capital*** }\end{array}$ & $\begin{array}{l}\text { No. } \\
\text { Projects }\end{array}$ & $\begin{array}{l}\text { Investment } \\
\text { Capital*** }\end{array}$ & No. Project & $\begin{array}{l}\text { Investment } \\
\text { s Capital*** }\end{array}$ & No. Projects & $\begin{array}{l}\text { Investment } \\
\text { Capital*** }\end{array}$ \\
\hline $1992 / 93$ & 542 & 3,750 & 3 & 233 & 0 & 0.00 & 545 & $3,983.0$ \\
\hline $1993 / 94$ & 521 & 2,926 & 4 & 438 & 1 & 57.00 & 526 & $3,421.0$ \\
\hline $1994 / 95$ & 684 & 4,794 & 7 & 505 & 2 & 39.00 & 693 & $5,338.0$ \\
\hline $1995 / 96$ & 897 & 6,050 & 10 & 434 & 1 & 6.00 & 908 & $6,490.0$ \\
\hline 1996/97 & 752 & 4,447 & 42 & 2,268 & 1 & 7.00 & 795 & $6,722.0$ \\
\hline $1997 / 98$ & 816 & 5,819 & 81 & 4,106 & 1 & 14.00 & 898 & $9,939.0$ \\
\hline $1998 / 99$ & 674 & 3,765 & 30 & 1,380 & 9 & $4,915.00$ & 713 & $10,060.0$ \\
\hline 1999/00 & 561 & 6,740 & 54 & 1,627 & 9 & $5,760.00$ & 624 & $14,127.0$ \\
\hline 2000/01 & 635 & $5,675.7$ & 45 & 2,923 & 7 & 257.00 & 687 & $8,856.0$ \\
\hline 2001/02 & 756 & $6,117.3$ & 35 & 1,474 & 10 & $1,598.80$ & 801 & $9,190.2$ \\
\hline 2002/03 & 1,127 & $9,362.9$ & 84 & 3,369 & 6 & 706.11 & 1,217 & $13,437.9$ \\
\hline $2003 / 04$ & 1,862 & $12,177.7$ & 347 & 7,205 & 16 & $1,837.04$ & 2,225 & $21,220.0$ \\
\hline 2004/05 & 2,240 & $19,571.7$ & 622 & 15,405 & 10 & $1,486.48$ & 2,872 & $36,463.3$ \\
\hline 2005/06 & 5,100 & $41,841.1$ & 753 & 19,980 & 6 & $18,215.08$ & 5,859 & $80,036.3$ \\
\hline 2006/07 & 5,322 & $46,630.1$ & 1,150 & 46,949 & 0 & 0.00 & 6,472 & $93,579.0$ \\
\hline $2007 / 08$ & 7,307 & $77,868.2$ & 1,651 & 92,249 & 3 & 261.56 & 8,961 & $170,378.5$ \\
\hline 2008/09 & 7,184 & $83,630.2$ & 1,613 & 73,111 & 10 & $82,783.52$ & 8,807 & $239,524.8$ \\
\hline $2009 / 10$ & 5,080 & $40,852.2$ & 1,413 & 55,169 & 3 & 393.89 & 6,496 & $96,415.4$ \\
\hline $2010 / 11$ & 5,360 & 42,093 & 952 & 53,357 & 10 & 154,019 & 6,322 & 249,469 \\
\hline \begin{tabular}{|l|} 
Total \\
\end{tabular} & 47,420 & 424,111 & 8,896 & 382,182 & 105 & 272,356 & 56,421 & $1,078,650$ \\
\hline
\end{tabular}

\section{Source: Ethiopian Investment Agency}

$* * *$ Investment capital is in millions of Birr

\section{Appropriate Solutions and Policy Strategies}

In establishing supply side policies for youth employment, equal emphasis has to be given to the demand side of the labour market as well. In other words, it is necessary to try to reduce unemployment by addressing the lack of skills or poor attitudes of young people while concentrating on promoting economic growth and job creation. With this mind, the recent double digit economic growth that Ethiopia witnessed has created job opportunity for many young Ethiopians. However, the public and private sectors have not created sufficient job opportunity nor has changed the structural weakness of the economy so far. This implies there is a need to pursue growth policies and strategies 
that are labour intensive. Those demand side labour market policies and strategies implemented by the government for employment generations including the special incentives and supports provided to private sectors and the public employment generation schemes has to be reinforced. That is, government investment into infrastructure development has to maintain its momentum and private sector development in the industrial sector has to be encouraged. Entrepreneurship has to be promoted making it easier to start and run enterprises in order to provide more and better jobs for young people; and employment creation has to be enhanced placing job creation at the centre of macroeconomic policy. Table 7 shows the 2008 to 2011 job opportunities and investment projects in Ethiopia.

Table 7: Recent Job Opportunity Records of Investment Projects

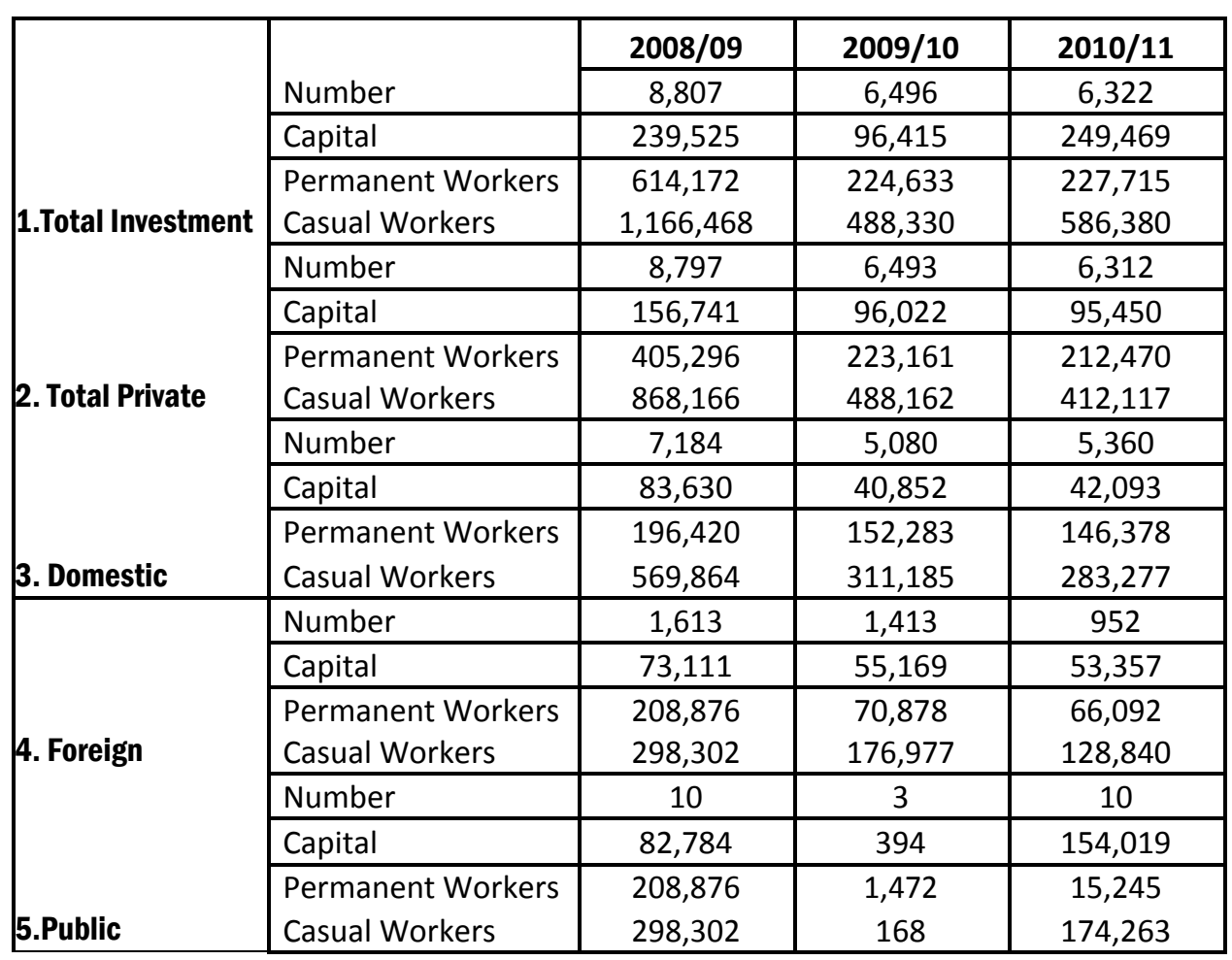

Source: Ethiopian Investment Agency

$* * *$ Investment capital is in millions of Birr 
Central to the promotion of economic growth and development is promotion of investment to the real sector of the economy. For this purpose, it is essential to periodically evaluate and revise the incentives provided for investment to redirect the allocation of the available capital to industrial development. The development of micro and small enterprises has to be strengthened, encouraged and facilitated by the government ministries or agencies in charge of this responsibility because the sector practically proved to be one of the fundamental solutions to urban youth unemployment in Ethiopia.

Enhancing the labour market information system through investments to improve information resources for youth is essential to avoid the mismatch between skills that educators entrust to their graduates and the technical skills that the economy requires. In a poorly developed labour market information system, many young people inevitably stumble in their initial career steps due to poor information about the world of work, leading to poor choices about education and careers. High quality labour market information and career guidance can help youth make better informed decisions about their future including the selection of academic/vocational programs, a decision to complete high school, and an optimal combination of education and work. The development of labour market information is also useful for the effective design and implementation of appropriate policies. Further, the collection, analysis and evaluation of labour market information are crucial to ensure that laws and policies are evidencebased and responsive to situations on the ground. Measures that can enable young people to have improved access to valuable information and opportunities, so that they might make informed decisions about their lives are important. To this end, it is important to enhance the capacity of the labour market institutions.

Although the integration of employment creation to urban housing development and inner city redevelopment is innovative, there is a need to address the administrative problems which lead to concerns of violation of the basic rights of the displaced people for reconstruction. It is, important to respect the rights of the people stipulated in domestic and the human rights laws that Ethiopia ratified. In order to sustainably exploit the potentials of employment creation and housing development there is the need to sufficiently involve those affected in the design and implementation of the programs and projects. There is a need to ensure that commensurate compensation to the value of properties of the relocated people is provided and the compensation is in compliance 
with the laws and policies issued to guide the resettlement when land is needed for redevelopment (Abebe \& Alemu, 2013).

A labour market study by World Bank (2007) proved that both the private sector brokers and the public sector labour market information providers are weak to serve the market function properly. This fact explains why employers have not been able to attract the most qualified. In a similar fashion qualified job seekers cannot find sufficient job and revert to personal networks to get employed. This means that the lack of the informal networks would lead to unemployment and other economic problems for qualified urban youth. Currently, the labour-market information system in Ethiopia is insufficiently developed to provide information for both job seekers and employers. Moreover, the available information on labour-market developments in the country is often fragmented and limited in scope or out-of-date. The situation in Ethiopia with this regard is similar to that of many sub-Saharan African economies (Dibie, 2014). The relevant labour market institutions which are causes of youth unemployment in Africa include labour demand barriers, such as observed discrimination by employers towards young people on the grounds of lack of experience. There is also the challenge of information gaps between job seekers and potential employers (United Nations Economic Commission for Africa, 2011). Hence, strengthening the labour-market information system is therefore very important so that it can play its intermediation role between the supply side and the demand side.

\section{Demand-side Policy}

Supply-side interventions can only be successful with complementary efforts that help to expand job opportunities for the youth. In an environment with low labour demand, young people will have a hard time finding a job, no matter what their skills level and educational attainment are. Thus, programs that generate jobs and foster local businesses are vital to reduce the prevalence of youth unemployment in urban areas (Ikatu, 2010). The following strategies are optional for the government to explore in the near future.

Reduced entry barriers by reducing experience requirements

1. Avoided discrimination on the basis of gender during recruitment process. 
2. Avoided discrimination during recruitment process on the basis of relationships, economic status, ethnicity, disability, etc.

3. Financially and/or technically support entrepreneurship

4. Organize and provide financial and technical support for youth to start their respective business.

5. Increased interests for government organization to hire youth.

6. Provides incentives for private sectors and NGOs to encourage them in hiring youth.

7. Promote investment in public works and labour-intensive infrastructure projects that can absorb youth in the nation.

\section{Supply-side Policy}

The supply side policies enable the youth to get prepared for the labour demand market. Thus, attention to strategies listed below is very essential. However, both employed and unemployed youth indicated the minimal level of government efforts in youth awareness creation. It is very important for the government to help youths to gain skills and training or education that has high labour market demand for the sustainable future.

Further, the Government of Ethiopia should establish training institutions at national and regional levels that exclusively focus on providing the needed skills for young people in the country. This kind of vocational training institutions could galvanize young people to start their own businesses. Regarding government's commitment in encouraging the youth to develop skills in technical and vocational training institutes, 88.8 percent and 28 percent of employed youth and unemployed youth agreed respectively. But, the majority (72 percent) of unemployed youth disagrees with such efforts by government. The differences in responses by respondents are also statistically at 5 percent significance level. From all these facts we can conclude that the matter of unemployed youth has not been effectively addressed to enable youths to gain vocational skills in the country. The following supply side policy strategies are options for the government to explore in the near future. 
1. Establish national vocational and technical training institutions that could provide appropriate training in the utilization of advanced technologies, and

2. Creating an opportunity for youth to easily join technical vocational educational training in order to gain education that leads to high skills in technological areas and experience in self-job creation.

3. Awareness creation for unemployed youth on employment opportunities.

4. Encourage youth to develop skill in technical and vocational training institutes

5. Establish policy for youth to participate in apprenticeship or internship when they are still in school to gain practical skills.

6. Help youth to get adequate training/ education that has high demand in the market.

7. Give training that help youth to start their own business rather than searching from other sector.

8. Produces enough food,

9. Preserves the integrity of ecosystems,

10. Uses resources efficiently (land, water, energy),

11. Uses renewable energy, and

12. Recycles nutrients

Capacity building is a continuous process of development that could be accomplished through the participation of the citizens in their own development. The dynamics of development and participation at both national and grassroots levels in Ethiopia must involves the exposure of government change agents to participatory learning and action (Bless, Higson-Smith, and Kagee (2006:15). Rather than government change agent directing in a top-down manner, they should assume a supportive, shared governance, and facilitative role. Government change agents should be willing to relinquish control over the relationship between change agent and community stakeholders in mutual social learning and capacity building process (Jones 2001; Theron, 2008). These principles if well implemented could ensure radical changes in thinking, 
planning, and training. After protracted planning and accompanying frustration, the role of facilitation can be assuming more practical and capacity-building dimensions. Sustainable development goals in Ethiopia should be based on the following orientations and alternative approaches. According to Francois Theron (2008), the following are areas that a nation could focus its capacity-building efforts:

1. Organizational training: This informal practical training in group dynamics, simple bookkeeping and accounting, adult literacy, banking and proposal writing.

2. Technical training: Technical capability is needed for developing countries to engage effectively in the global economy; direct foreign investment, international trade, mobility of engineers, and the flow of work to countries with cost-effective talent will result. This based on needs and priority defined by the people themselves. Training opportunities in various skills need to be arranged either externally or internally.

3. Indigenous science and technology capacity: Indigenous science and technology capacity is needed to insure that international aid funds are utilized effectively and efficiently - for initial project implementation, for long-term operation and maintenance, and for the development of capacity to do future projects. And a sufficient pool of engineers can enable a developing country to address the UN's Millennium Development Goals effectively, including poverty reduction, safe water and sanitation, etc.

4. Technical Workforce Pool: In order to stimulate job formation in developing countries, a technical workforce pool is needed, made up of people who are specifically educated and prepared to engage in entrepreneurial start-up efforts that meet local needs.

5. Leadership Development: This is informal training in leadership development and the planning, implementation and evaluation of projects.

6. External Linkages and Capacity Building. People need to be assisted in establishing linkages and building networks with external agencies. Part of this 
process is helping people to acquire the skills, confidence and capacity required in establishing and maintaining such linkages.

7. Exchange of Experiences: People should be assisted in arranging visit to, and exchange with similar groups, projects, training and research centres, and attending internships, on-the-job training sections, of-the-job conferences, workshops and fieldtrips (Chambers 2002; 2005).

8. Support and Encouragement: The presence of the change agent living and working in the country and sharing the experiences and problems of the people is often a decisive factor in encouraging people to persevere in their early efforts to improve their own lives. Once a sustainable participatory development projects has been initiated it should become a neither continuous process with no visible end to it. Theron (2008) contends that the only thing that should end the project is the intervention of the change agent who should withdraw as soon as the local citizens can maintain the development project or process.

9. International Experience: The formulation of policies for a developmental state not only requires ongoing work within the state, but also the capacity to rapidly learn from international experience. It should be the objective of government in the medium term is to strengthen its engagement with society and with social partners. This can be achieved by, amongst other things, improving the function and capability of institutions, strengthening the participation of organised sectors of society within them, and by enhancing the capacity of representative bodies by, among others, improving their research and representative support capacity on economic development and industrial policy. Without this capacity, it is more likely that the environment for engagement will be reactive and that productive partnerships will not emerge.

10. Economic Sustainability Strategy: Economic sustainability is an actionable strategy companies engage in to ensure they remain a going concern. Different strategies include lean accounting or management, competitive market analysis, product differentiation, concentrated growth, or similar strategies. A nation's operating environment will rarely remain static; external forces will pressure the country to make changes to public and business practices that will help the 

economies.

Finally, It is very important to note that capacity building projects that has foundation behaviour and attitudes, methods and sharing planted in the humanist paradigm, offers not only the basis for self-reliance, participatory development but a means and an end in itself.

\section{Conclusions}

This paper has examined the problem of capacity building and youth unemployment in Ethiopia. It argues that the reason for Ethiopia's high youth unemployment rates is the negative correlation between educational systems and the technical skills needed in the labour market, and small private sectors because these informal industries are unable to employ large numbers of people. Technically capacity building in Ethiopia will serve as a lever for economic and social development (Russell Jones, 2001). This fact is currently being recognized as an important priority in the global sustainable community.

The author pointed out that youth unemployment is a critical problem in urban Ethiopia, with a high incidence in the city of Addis Ababa. The unemployment problem tends to affect more female than male in the country. The research evaluated the youth unemployment situation in Ethiopia between 1999 and 2011. Other relevant reasons include labour demand barriers, such as observed discrimination by employers towards young people on the grounds of lack of experience; information gaps between job seekers and potential employers and barriers to the creation and development of business opportunities, particularly in gaining access to financial, physical and social capital. Equally important reason is the performance of the economy. The economy is structurally weak and dominated by the agricultural and service sectors with the contribution of the industrial sector limited to about $13 \%$ in the gross domestic product.

Although, the Ethiopian Government has developed strategies to accelerate economic growth in the areas of infrastructure, telecommunications, tourism, education, health and private sector development, among others. In the service sector there has been a rapid growth in the retail trade, tourism, transportation, financial services and real estate. All this shows the scope for further expansion in various economic sectors which will create 
a considerable number of job opportunities for the youth. There is still a lot that the Government of Ethiopia must do in the area of renewable energy, sustainable communities, green economy and the recycling of use products

The finding of this paper shows that enormous efforts have gone into building young Ethiopian's knowledge and skills through the provision of basic levels of education and vocational training. However, in the new global economy, young people need to acquire more than just basic education, and curricula should be influenced by the current rate of globalization, regional integration and technological transformation (Russell Jones, 2001 p. 7). Investing in education and technical skills for young people should therefore go beyond increasing basic literacy rates to assure dynamic, multifaceted knowledgebuilding at higher and tertiary levels. This will go a long way in preparing young people for the evolving labour market. Although there has been a considerable increase in primary school enrolment, in Ethiopia on course to achieving the targets of universal primary education and gender parity in education, access to quality tertiary education is still a challenge for young people.

In order to increase job absorption by the private sector, incentive packages, such as special tax breaks to promote persistent youth-labour-intensive investments, should be considered by the government rather than giving uniform tax advantages to all private firms (Merrick Jones, 2001). Strategies for creating an enabling environment for the private sector and NGOs should be clearly defined in the national youth policy. In addition, the strategy that enhances the collaboration of government, the private sector and NGOs to deal with urban youth unemployment should be designed and implemented accordingly. There should be periodical forums in which potential private sectors, NGOs and government participate to discuss issues related to urban youth unemployment (Nwazor, 2012). The youth employment policy should be revised to explore employment opportunities, not only domestically but also outside Ethiopia for expatriate and labourers by giving incentives to relevant agencies to engage in information sharing, promotion, and the facilitation of youth employment abroad. The established public labour-intensive infrastructure projects in urban areas, like cobblestone, housing, Micro and Small Enterprises and others, need to be strengthened and supported by government, private sectors and NGOs, both technically and financially. Higher institutions of learning and technical vocational educational training programs should periodically revise their curricula, and focus on fields of study which 
have a high market demand to absorb graduates. More-over, they should be able to create a linkage with potential government institutions, private companies and industries, international and national NGOs, and other stakeholders to enhance schools to work towards transition.

If Ethiopian youth are to be competitive in the new and very competitive global economy, all stakeholders, including federal and regional governments, the private sector, and civil society, faith-based and youth-focused organizations should strengthen cooperation and partnerships to ensure that returns from both formal and non-formal education bring about highly productive outcomes in the labour market. Finally, how people preserve or abuse the Ethiopian environment will largely determine whether capacity building and living standards improve or deteriorate. Growing human numbers, urban expansion, and resource exploitation do not resonate well for the future. Without seeking capacity building and practicing sustainable development behaviour, the citizens of Ethiopia may face a deteriorating environment as well as even invite ecological disaster.

\section{List of References}

- $\quad$ Abebe T, \& K. Aelmu. 2013. Analysis of Urban Youth Unemployment in Ethiopia: The Case of Addis Ababa. Journal of International Politics and Development Vol, 11, no 1 \&2, pp.131-162

- Adebayo, A.1999. "Youth unemployment and National Directorate of Employment and self-employment programmes". Nigerian Journal of Economics and Social Studies 41 (1), 81-102.

- Argyris, C. and Schon, D. (1978) Organisational Learning: Theory, Method and Practice. Reading, MA: Addison-Wesley .

- Alamgir, M. 1989. Participatory Development: the IFAD Experience. In Lineberry, W. P. (ed.). Assessing Participatory Development: Rhetoric versus Reality. Boulder, CO: Westview Press

- Anderson, James. 2015. Public Policy Making. Stamford, CT: Cengage Learning

- $\quad$ Anderson, James. 2011. Public Policy Making. Boston, M.A.: Wadsworth Press 
- Ashenafi Gossaye .2008. Inner-City Renewal in Addis Ababa: The Impact of Resettlement on the Socio-Economic and Housing Situation of Low-Income Residents, First ed. VDM Verlag Dr. Muller Aktiengesellschaft \& Co. KG, Saarbrücken.

- Azikiwe, U. 2008. Standard in Tertiary Education: Capacity Building and Sustainable Development in Nigeria. A lead paper presented at the Annual Conference of the Faculty of Education, Nnamdi Azikiwe University, Awka, Anambra State.

- Barron, P, and Sankar, U. 2001. Development towards a District Health System. Durban, South Africa: Health System Trust Publication.

- Beazley, H. and Ennew, J. 2006. Participatory Methods and Approaches: Tackling the Two Tyrannies. In Desai, V. and Porter, R. B. Doing Development Research. London: Sage Publication

- Boxer, Lionel. 2011. "Preparing Leaders for Sustainable Future." International Journal of Business Insights and Transformation, Vol. 3, (January), 34-43.

- Braungart, Richard G., 1984. 'Historical and Generational Patterns of Youth Movements: A Global Perspective', Comparative Social Research 7(1): 3-62.

- Borowski, Al.1984. A Comparison of Youth Unemployment in Australia and the United States\|, Monthly Labour Review,Vol 107, pp.30-36

- Brooks, C. 2012. What is fiscal policy? Business News Daily, Retrieved from http://www. businessnews daily.com /3484-fiscal-policy.html. Accessed April 12, 2014.

- Brown, M. M. 2004. Human Development Report. New York: United Nations Development Program.

- Brown, C.J. 1997. The Societal Dimension of Projects Management. Management Dynamics 6 (5): $69-87$.

- Chambers, R. 2005. Ideas for Development. London, England: Earthscam Press.

- Chambers, R. 2002. Participatory Workshop: A Sourcebook of 21 Sets of Ideas and Activities. London England: Earthscan Press.

- Choucri, Nazli.1974. Population Dynamics and International Violence: Propositions, Insights and Evidence. Lexington, MA: Lexington.

- Cincotta, Richard P.; Robert Engelman \& Daniele Anastasion. 2003. The Security Demographic: Population and Civil Conflict after the Cold War. Washington, DC: Population Action International. 
- Collier, Paul. 2000. 'Doing Well Out of War: An Economic Perspective', in Mats Berdal \& David M.

- Collier, Paul \& Anke Hoeffler. 2004. 'Greed and Grievance in Civil War', Oxford Economic Papers 56: 563-595

- Conyers, D. and Hills, P. 1990. An Introduction to Development Planning in the Third World. New York: John Wiley.

- Dendir, S. 2006. Unemployment Duration in Poor Developing Economies: Evidence from Urban Ethiopia. The Journal of Developing Areas, R23, J64, 055

- Denu, Berhanu, Abraham Tekeste and Hannah Van Der Deijl. 2005. Characteristics and determinants of youth unemployment, underemployment and inadequate employment in Ethiopia. Employment strategy papers International Labour Organization.

- Dibie, R. 2014. Comparative Perspective of Environmental Policies and Issues. New York, N.Y.: Routledge Press. .

- Dibie, R. 2010. Social Impact of Environmental Policies in Ethiopia. Journal of International Politics and Development, vol. 8, no. 1, pp.1-32.

- Dye, Thomas. 2011. Understanding Public Policy. 13 $3^{\text {th }}$ Edition. New York: Longman, pp. 210-231.

- Echebiri, R.N. 2005. Characteristics and Determinants of Urban Youth Unemployment in Umuahia, Nigeria: Implications for Rural Development and Alternative Labour Market Variables. A Paper presented at the ISSER/Cornell/World Bank conference on "Shared Growth in Africa" held in Accra, Ghana, July 21-

- Eita, J.H. and Ashipala, J.M. 2010. Determinants of Unemployment in Namibia. International Journal of Business and Management, 5(10), 92-104.

- Englama, A. 2001. "Unemployment: Concepts and Issues." Bullion Publication of the Central Bank of Nigeria 25 (4), 1-6.

- Eyob, D.2010. Urban Renewal and Resettlement Practices in Addis Ababa: Alternative for Eviction, Paper Presented for Refresher Course Organized by IHS Alumni of Kenya and IHS edn, Kenya IHS Alumni, Nairobi.

- Esman, M. J. 1991. Managing Dimension of Development: Perspectives and Strategies. Connecticut, Kumariam Press. 
- Ethiopia Central Statistical Authority/CSA.. 1999. National Labour Force Survey. Addis Ababa, Ethiopia.

- Ethiopia Central Statistical Authority/CSA. 2003. Urban Bi-Annual Employment Unemployment Survey. Addis, Ethiopia

- Ethiopia Central Statistical Authority/CSA. 2004. Urban Bi-Annual Employment Unemployment Survey. Addis Ababa, Ethiopia.

- Ethiopia Central Statistical Authority/CSA. 2005. National Labour Force Survey. Addis Ababa, Ethiopia

- Ethiopia Central Statistical Authority/CSA. 2006. Urban Employment Unemployment Survey. Addis Ababa, Ethiopia.

- Ethiopia Central Statistical Authority/CSA. 2009. Urban Employment Unemployment Survey. Addis Ababa, Ethiopia.

- Ethiopia Central Statistical Authority/CSA. 2010. Urban Employment Unemployment Survey. Addis Ababa, Ethiopia.

- Ethiopia Central Statistical Authority/CSA. 2011. Urban Employment Unemployment Survey. Addis Ababa, Ethiopia.

- Ethiopian Economic Association. 2005/06. Report on the Ethiopian Economy, Unemployment Challenges and Prospects, Volume V, Addis Ababa, Ethiopia

- Ethiopia Central Statistical Authority. 2012. 'Urban Employment Unemployment Survey'. Addis .Ababa, Volume 1 and 2, Addis Ababa, Ethiopia

- Ethiopian Investment Agency. 2011. Number of Investment Capital of Approved Projects by Ownership. Addis Ababa, EIV Publication.

- Ezana H. Woldegebriel.2011. Factors Influencing Affected Group Participation in Urban Redevelopment in Addis Ababa: The Case of Senga Tera-Fird Bet I Project; International Institute of Urban Management, Erasmus University of Rotterdam

- Freeman, R. and D. Wise (eds.) 1982. "The Youth Labour Market Problem: Its Nature, Causes and Consequences", University of Chicago Press.

- Falae, S.O.1971. "Unemployment in Nigeria". Nigerian Journal of Economics and Social Studies 13(1) 65 
- Federal.Democratic .Republic of .Ethiopia. 1994. The Constitution of the Federal Democratic Republic of Ethiopia: (unofficial English translation from the Amharic original), The Republic, Addis Ababa.

- Federal.Democratic .Republic of .Ethiopia 2005. Expropriation of Land for Public Purposes Proclamation No. 455/2005, Land Law edn, Ethiopia, Addis Ababa

- Federal.Democratic .Republic of .Ethiopia. 2004. Labour Proclamation no.377/2003, A.A., Ethiopia

- $\quad$ Federal.Democratic .Republic of .Ethiopia. 2004. National Youth Policy. Policy report, Addis Ababa, Ethiopia

- Federal.Democratic .Republic of .Ethiopia. 2009. Employment Exchange Services. Proclamation no. 632/2009, A.A., Ethiopia

- $\quad$ Federal.Democratic .Republic of .Ethiopia and International Labour Organization. (2009). Decent Work County Program (DWCP) Ethiopia (2009-2012), A.A., Ethiopia.

- Federal Democratic Republic of Ethiopia. (2009). "Charities and Societies Proclamation", (621/2009). Addis Ababa

- $\quad$ Ferrel O. C., Geoffrey Hiirt \& L. Ferrell. 2011. Business: A Changing World. New York, N.Y.: McGraw Hill Press.

- Guarcello, L. and Rosati, F. 2007. Child Labour and Youth Employment: Ethiopia Country Study. SP Discussion Paper No.0704. The World Bank

- Gibb, A.A. and George, M.1990. "The Design of Extension and Related Support Services for Small scale Enterprise Development". International Small Business Development Journal 8 (3) $10-12$.

- Huntington, Samuel P.1996. The Clash of Civilizations and the Remaking of World Order. New York: Simon \& Schuster.

- Haile, Getinet Astatike. 2003. "The incidence of youth unemployment in urban Ethiopia." NBE .2011. National Bank of Ethiopia: Annual Report

- Homer-Dixon, Thomas F., 1999. Environment, Scarcity, and Violence. Princeton, NJ: Princeton University

- Hoover, K. D. (2008). Phillips curve. Library of Economics and Liberty, Retrieved from http://www.econlib.org/library/Enc/PhillipsCurve.html. Accessed April 11, 2014. 
- Ikatu International. (2010). Global Youth Employment: An Overview of Need and Interventions. Revised Report.

- Ikharehon, J.I. 2007. Capacity Building for National Sustainable Development. The Nigerian Experience. Journal of Social Sciences. (154), 25-29.

- International Labour Organization (ILO). 2012. Global Employment; a global goal a national challenge. The International Labour Organization. Geneva.

- International Labour Organization (ILO) .2012. Global Employment Trends for Youth. Geneva.

- International Labour Organization (ILO). 2011.Global Employment Trends for Youth. Geneva.

- International Labour Organization (ILO). 2011. Key Indicators of Labour Market, 7th Edition. Technical report International Labour Organization.

- International Labour Organization (ILO). 2008. Global Employment Trends for Youth, 2008. Geneva: The International Labour Organization

- International Labour Organization (ILO). 2008. "Skills for Improved Productivity Employment Growth and Development."www. ILO.org/public/English/employment/skills/download/iloreport.pdf

- Jones, Russell. 2001. Engineering Capacity Building in Developing Countries to Promote Economic

Development.www.worldexpertise.com/Engineering_Capacity_Building_in_Developing_ Countries .htm. Accessed March 19, 2014.

- Jones, Merrick. 2001. Sustainable Organizational Capacity Building: Is Organizational Learning a Key? International Journal of Human Resource Management 12:1 February 2001 91-98

- Katsioloudes, Marios. 2006. Strategic Management: Global Culture Perspectives for profit and Nonprofit Organizations. New York, N.Y.: Elsevier Press

- Kibrom Tafere. 2010. The Sources of Inflation in Ethiopia, Lap Lambert Academic Publishing

- Kraft, Michael, and Scott Furlong. 2013. Public Policy: Politics, Analysis, and Alternatives. Washington D.C.: Congressional Press, pp. 322-337. 
- Kolb, D., Rubin, I. and McIntyre, H. (1971) Organisational Psychology: an Experiential Approach. New Jersey: Prentice Hall.

- Labour of Social Affairs Bureau. (2013). Unemployment Survey in Addis Ababa Region; Addis Ababa: Government Press.

- Lehane, Richard. 2012. Government and Business. Washington D.C.: Congressional Quarterly Press.

- Lishan Seyoum. 2010. Socio-Economic Impacts of Relocation in Addis Ababa: The Case of Relocatees From Sheraton Hotel and Economic Commission for Africa (ECA) Areas, Masters of Arts Education, Addis Ababa University, Addis Ababa.

- Mandel, M. 2012. Economics: The Basics. New York, N.Y.: McGrall Hill Press.

- Mankiw, Gregory. 20012. Macroeconomics. New York, N.Y.: McGraw Hill Press

- Mangozho, Nicholas. 2002. Current Practices in Labour Market Information Systems Development For Human Resources Development Planning in Developed, Developing and Transition Economies. International Labour Office. Geneva.

- Mangozho, N. 2001. "Higher Education and Labour Market Dynamics: The Case of Zimbabwe" (MA Research Paper- Institute of Social Studies, the Netherlands).

- Machunovich, Diane J., 2000. 'Relative Cohort Size: Source of a Unifying Theory of Global Fertility Transition?', Population and Development Review 26(2): 235-261.

- Martha Kibru. 2012. Employment Challenges in Ethiopia,

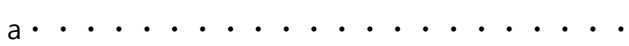

- $\quad$ Miller R., Benjamin, D. and D. North. (2014). The Economics of Public Issues. Boston, M.A.: Pearson

- Ministry of Education. 2008. National Technical \& Vocational Education \& Training (TVET) -Strategy Ministry of Education, Addis Ababa.

- Ministry of Education .2002. The Education and Training Policy and its Implementation. Policy report Ministry of Education, Addis Ababa, Ethiopia.

- Ministry of Education .2008. National Technical and Vocational Education and Training Strategy. 2nd edition Ministry of Education, Addis Ababa, Ethiopia.

- Ministry of Finance Economic Development .2010. Growth and Transformation Plan (2010/11-2014/15). Volume I: Main text Ministry of Finance and Economic Development (MoFED), Addis Ababa, Ethiopia. 
- National Bank of Ethiopia. 2012. Sectorial Gross Domestic Product. Addis Ababa, NBE Publication

- Nebil, K., Gezahegn, A., and Hayat, Y. 2010. Enabling the Private Sector to Contribute to the Reduction of Urban Youth Unemployment in Ethiopia. Addis Ababa Chamber of Commerce and Sectoral Associations, Addis Ababa.

- Nwazor, J. C. 2012. Capacity Building, Entrepreneurship and Sustainable Development. Journal of Emerging Trends in Educational Research and Policy Studies (JETERAPS) 3 (1): $51-54$

- Nzinga H. Broussard and Tsegay Gebrekidan .2012. Youth Unemployment: Ethiopia Country Study; International Growth Centre Working paper 12/0592 London School of Economics and Political Science

- Okojie, C.E.E. 2003."Employment creation for the youths in Africa." International Journal of Adolescence and Youth 1(131), 1-13.

- Olivier de Sardan, J. P. 2005. Anthropology and development: Understanding Contemporary Social Change, London, Englnad:Zed Books.

- Onah, F.O. 2010. "Urban Unemployment Situation in Nigeria." In Ezeani, E. O., Otaki, O. A. 2003. Youth Unemployment in Nigeria: Some Implication for the Third Millennium. Global Journal of Social Sciences 2 (1) 21-26.

- Theron, Francois. 2008. The Development Change Agent. Pretoria, South Africa: Van Schail Press.

- Theron, Francois. 2005. Trends in Micro-level Development. In David I, Theron F., Maphunye, K. Participatory Development in South Africa. Pretoria: J. L. van Scaik Press.

- UNECA. 2011. Africa Youth Report: Addressing the Youth Education and Employment Nexus in New Global Economy.

- Olivier de Sardan, J. P. 2005. Anthropology and Development: Understanding Contempoary Social Change. London, England: Zed Books Onah, F.O.2010. "Urban Unemployment Situation in Nigeria". In:

- Ezeani, E.O. and Otaki, O.A. (2003). Youth Unemployment in Nigeria: Some Implication for the Third Millennium. Global Journal of Social Sciences 2 (1) 21-26.

- $\quad$ Peters, Guy. 2013. American Public Policy. Washington D. C.: Congressional Quarterly Press 
- Porter, T. B. 2006. Co-evolution as a Research Framework for Organization and the Natural Environment, Organization and Environment, 19 (4) 479-503.

- Rafik, M., Ahmad, I. Ullah, A. And Khan, Z . 2010. Determinants of Unemployment: A Case Study of Pakistan Economy (1998-2008). Abasyn Journal of Social Sciences, 3(1).

- Rajagopal, Balakrishnan. 2003. International Law from Below: Development, Social Movements, and Third World Resistance. Cambridge: Cambridge University Press.

- $\quad$ Revans, R.W. 1980. Action Learning. London: Blond \& Briggs.

- Revans, R.W. 1991. International Perspectives on Action Learning. Manchester: Institute for Development Policy and Management, University of Manchester .

- Rondinelli, D. A. 1993. Development Projects as Policy Experiments: An Adaptive Approach to Development Administration. London, England: Routledge Press

- Schiller, Bradley. 2011. Essentials of Economics. New York, N.Y.: McGraw Hill Press.

- Smith-Sebasto, N. 2012. Sustainability. New York, N.Y.: McGrall Hill Press.

- SparkNotes. 2013. Problems with monetary policy and fiscal policy. Retrieved from http://www.sparknotes.com/economics/macro/policydebat. Accessed April 12, 2014.

- Steven Kapsos. 2005. The employment intensity of growth: Trends and macroeconomic determinants. Employment Strategy Papers; International Labour Office

- Tegegn Gebeyaw and Tesfaye Chofana .2012. Youth unemployment trend and its association with education and training in urban Ethiopia evidence using pooled cross sectional data from urban employment-

- United Nations. 2010. Millennium Development Goals report, http://www.un.org/millenniumgoals/ pdf/MDG\%20Report\%202010\%20En\%20r15\%20low\%20res\%2020100615\%20-.pdf

- United Nations. 2012. Human Development Index. New York, N.Y.: Oxford University Press

- United Nations Development Program (UNDP). 2004, 2005 \& 2006. Human Development Report. UNDP, New York: Oxford University Press.

- United Nations Development Program. 2003. Human Development Report. UNDP, New York: Oxford University Press. 
- Un-Habitat. 2011. Condominium Housing in Ethiopia: The Integrated Housing Development Programme. Housing practices series United Nations Human Settlements Programme: Nairobi, Kenya.

- World Bank. (2011). Ethiopia Protection of Basic Services Phase 2 Project. Washington, D.C.: World Bank.

- World Bank. 2009. Ethiopia: The Employment Creation Effects of the Addis Ababa Integrated Housing Program

- World Bank. 2007. Ethiopia: Urban Labour Markets in Ethiopian: Challenges and Prospects. Synthesis Report. Vol I \& II.

- World Bank. 2009. Ethiopia: The Employment Creation Effects of the Addis Ababa Integrated Housing Program.

- World Bank. 2007. Ethiopia: Urban Labour Markets in Ethiopian: Challenges and Prospects. Synthesis Report. Vol I \& II.

- World Bank. 2003. World Bank Development Report. New York: Oxford University Press.

- World Bank. 2002. Empowerment and Poverty Reduction: A Sourcebook. Washington D. C.: World Bank Publication.

- World Bank. (1998). 1998 World Development Indicators. Washington, D.C.: World Bank.

- World Commission on Environment and Development. 1987. Our Common Future. New York: Oxford University Press.

- Woldehanna, Tassew, John Hoddinott and Stefan Dercon. 2008. "Poverty and Inequality in Ethiopia: 1995/96-2004/05." Social Science Research Network.

- Woldengariel, T. 2011. Filtu Farmer Development Irrigation." The Ethiopian Herald, February 8, pp. 2-4.

\section{AUTHORS' CONTACT:}

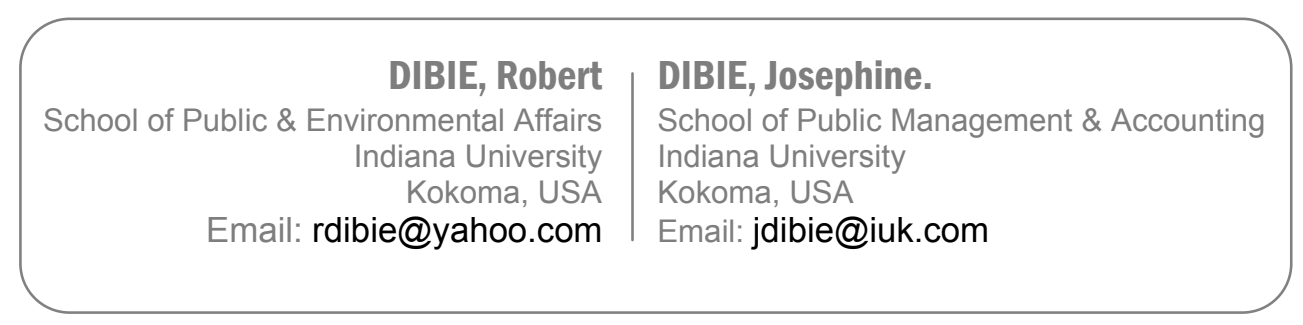

